\title{
Rewriting Earnings History
}

By

\author{
Baruch Lev, ${ }^{*}$ Stephen G. Ryan, ${ }^{*}$ and Min $\mathrm{Wu}^{* *}$
}

February 2007

\footnotetext{
${ }_{* *}^{*}$ Stern School of Business, New York University.

${ }^{* *}$ Hong Kong University of Science \& Technology.

We appreciate the comments of Mary Barth, Bill Beaver, Thomas Dyckman, Paul Griffin, Russell Lundholm, Sarah McVay, Craig Nichols, and Nir Yehuda, of seminar participants at Florida State University, New York University, Cornell, and Stanford's Accounting Summer Camp, and particularly those of an anonymous reviewer and Jim Ohlson, the editor.
} 


\begin{abstract}
Research on the usefulness of financial information generally focuses on the innovation in the information examined, such as an earnings surprise or cash flow growth. Consequently, prior research sheds little light on the role of the rich historical record of financial information in users’ decision-making. Using a sample of published restatements of earnings, we show that the revision of the historical pattern of earnings, distinct from the magnitude of the restatement and its impact on current earnings, significantly affects investors' decisions and predicts class action lawsuits. Specifically, we find that restatements that eliminate or shorten histories of earnings growth or positive earnings have significantly more adverse effects for investor valuations and the likelihood of lawsuits than other restatements. This evidence about the value-relevance of refreshing the historical record of earnings is pertinent to the FASB's recent cautious expansion of the scope of circumstances that require a restatement of financial information in FAS 154.
\end{abstract}

Keywords: Historical record, revisions, financial information, investors’ decisions, class action lawsuits. 


\section{Rewriting Earnings History}

\section{INTRODUCTION}

In this study we examine the unique setting of earnings restatements - the rewriting of earnings history_-in which revisions to previously reported earnings are recognized in amended financial statements (rather than just disclosed in financial reports as is required, for example, for property-casualty insurers' loss reserve development). ${ }^{1}$ In contrast to prior research on earnings restatements, which primarily focuses on the total magnitude of restatements, we examine restatements' effects on the firm's historical pattern of earnings that we expect to have significantly adverse implications for the firm and its investors. We predict and find that earnings restatements that eliminate or shorten histories of earnings growth or positive earnings trigger a stronger negative market reaction to the restatement announcement and increase the likelihood of class action lawsuits, compared to restatements which do not affect the historical pattern of earnings in these ways. We control in our analysis for the effects of restatements on the magnitudes of current and lagged earnings and for various attributes of restatements that the prior literature has found to be associated with investor reaction and the likelihood of class action lawsuits.

This study contributes to and in certain respects marries research examining the consequences of earnings restatements with research examining the value-relevance of the historical record of financial information. The first of these strands of research shows that earnings restatements are relevant to investors and related to important events, such as the filing of class action lawsuits and changes in the cost of capital. We extend this research strand by showing that the elimination of past earnings growth or positive earnings patterns, as distinct 
from the magnitude of the restatement and its effect on current earnings, impacts stock prices and lawsuit likelihood. Thus, the rewriting of earnings history (past patterns) matters.

With respect to the second research strand—-the value-relevance of the historical record of financial information - we provide empirical evidence demonstrating such relevance in the specific context of earnings restatements. This contribution, we believe, is of considerable importance because of the paucity of empirical evidence in this area. This is due, in part, to the widespread belief that most users focus on current financial information and quickly lose interest in historical data. Such an evidently wrong view is expressed, for example, in APB 20 (para. 14): "Restating financial statements of prior periods may dilute public confidence in financial statements and may confuse those who use them.”

Similarly, researchers typically focus on identifying and analyzing the innovation component of financial information, that is, the new or unexpected part of the message. ${ }^{2}$ For example, the large body of research on the returns-earnings relation initiated by Ball and Brown (1968) primarily examines the market's reaction to unexpected earnings, and earnings management research mainly focuses on unexpected (or abnormal) accruals. Researchers rarely attend to the rich historical record of financial report information and thus shed little light on users' interpretation of that record or how new information interacts with it. ${ }^{3}$

Our findings, in contrast, indicate that significant revisions in the historical pattern of earnings have important implications for the firm and its investors. Such findings are clearly relevant to the renewed interest of regulators in expanding the revision of historical financial records, as manifested in the FASB's issuance of FAS 154 and more generally by the substantial increase in the frequency of earnings restatements in recent years, many of which have been prompted by the SEC. 
The remainder of this paper is organized as follows. Section II provides a conceptual analysis of the rewriting of financial histories. In Section III we summarize the related research and discuss how our paper contributes to that research. In Section IV we outline our hypotheses and describe the general structure of our empirical models. In Section V we discuss the sample, test variables, and descriptive statistics, and in Section VI we report the empirical results for the returns analysis. In Section VII we present the findings of the class action lawsuit analysis, and Section VIII concludes the study.

\section{The Rewriting of Financial Histories}

How does the historical record of financial report information affect users' decisions? Accounting data, like any other historical record, portray a process of development that links individual observations, such as financial statement line items, across time (e.g., a pattern of sales growth) and to external conditions and events (e.g., tax rate changes). In such a process of development, an individual observation, be it an earnings surprise or unexpected accruals, cannot be interpreted in isolation, abstracting from the history of the process or the impact of the observation on that history. ${ }^{4}$ For example, it has been shown that the size of accounting accruals varies with the life cycle of the enterprise, being relatively large for young, fast-growing companies and decreasing as the firm matures (Khan, 2005). In this case, the firm's history of accruals contains information about its development stage and, in turn, about its current and expected accruals; conversely, the firm's current accruals provide information about its stage of development. Accordingly, a researcher who focuses only on the relation between current accruals and a variable of interest, such as share returns, ignores the interactions between the firm’s lifecycle stage and both historical and current accruals and therefore misspecifies the true, 
underlying relation between accruals and returns. For instance, high accruals at an early stage of a firm's life cycle suggest it is making the investments required of such firms, and accordingly such accruals should have less adverse valuation implications than they would for a mature company, for which large accruals suggest earnings management.

Similarly, since the historical records of economic data are important for the interpretation of new economic or social information and events, it is not surprising that such records are routinely revised (refreshed) to improve their usefulness. For example, macroeconomic data, such as gross domestic product (GDP), are periodically revised by the Bureau of Economic Analysis (BEA) in light of new information. The first estimate of quarterly GDP is released several days before the end of the quarter, based solely on projections of the yet to be realized value. This figure is revised soon after the end of the quarter with estimates based on sampling and other approximation techniques of the now realized, although not fully known, GDP value, followed by yet another revision a few months later based on realizations of certain estimates and refined approximations. Lastly, every five years the entire record of the national accounts is revised based on the best available information about the realizations of prior estimates. The essence of these revisions of macroeconomic data is the continuous use of new information to update and correct the previously published historical record. Empirical evidence indeed indicates that such revisions of macroeconomic data are highly relevant to decision makers. $^{5}$

Despite the frequency and relevance of revisions of historical records in other economic and social contexts, with one notable exception discussed below, generally accepted accounting principles (GAAP) require the restatement of earnings only in the unusual circumstances of identified errors or fraud. Specifically, APB 20 requires restatements in case of “[e]rrors in 
financial statements result from mathematical mistakes, mistakes in the application of accounting principles, or oversight or misuse of facts that existed at the time the financial statements were prepared” (para. 13). Except for a few cases (e.g., FAS 146), accounting standards do not even require the disclosure of revisions of accrual estimates underlying the computation of earnings. As summarized in FAS 16, most extant GAAP rules convey the belief that the historical record of financial information should reflect the estimates and projections made at the time of disclosure, and hence the originally published record should not be revised even when new information contradicts prior assumptions and projections, except in rare cases.

Recent actions by the FASB, however, suggest that it is moving cautiously towards requiring firms to refresh the historical record of financial report information in a wider context. Most notably, FAS 154, issued in May 2005, requires firms to restate past financial statements for voluntary accounting changes. In the summary of this standard, the FASB states that such restatement will improve financial reporting by "enhancing the consistency of financial information between periods." While FAS 154 constitutes a significant change from prior GAAP (APB 20), it still is a far cry from the more ambitious proposals by academics that firms be required either to restate past financial statements based on newly revealed information, or disclose revisions of major accrual estimates based on such information, in order to provide better information about firm risk (Ryan 1997), to support credible voluntary disclosures (Lundholm 1999), or to curb earnings manipulation (Lev 2003).

While the empirical work in our study is limited to the specific context of restatements of earnings under existing accounting rules, our findings that revisions to the historical pattern of earnings have significant valuation implications and other consequences (lawsuits) are consistent with the view that accounting standards should be extended in the direction of requiring revision 
of the historical record of earnings under a broader set of circumstances than is currently prescribed. This view is further supported by the fact that our findings regarding the valuation implications of pattern-disrupting restatements are mainly driven by sample observations in which the restating firm did not admit fraud. So, it is not the extreme case of fraud where reporting of changes in the pattern of historical earnings is critical, rather it is the more normal cases of inadvertent misapplication of accounting rules, whether due to managers' insufficient understanding of the firm's circumstances or to deficiencies in their accounting policies and systems. We elaborate on this point in the conclusion.

\section{Related Research}

\section{Earnings Restatements}

It is widely recognized that earnings restatements constitute a powerful—although not necessarily representative—-setting in which to examine the circumstances, determinants, and consequences of earnings management. ${ }^{6}$ The restatements/earnings management literature has two distinct phases: The earlier work focuses on specific cases of Securities and Exchange Commission (SEC) enforcement actions (Feroz et al. 1991; Dechow et al. 1996; Bonner et al. 1998; Beneish 1999) and accounting errors (Defond and Jiambalvo 1991), whereas the more recent literature (Griffin 2003; Palmrose et al. 2004; Palmrose and Scholz 2004; Hribar and Jenkins 2004; Anderson and Yohn 2002; Wu 2002; Richardson et al. 2003) examines multiple types of earnings restatements, sometimes focusing on the more frequently restated line items such as revenue (Callen et al. 2003) or in-process research and development costs (Dowdell and Press 2001; Banyi 2006). 
Three studies—Palmrose et al. (2004; hereafter PRS), Anderson and Yohn (2002; hereafter AY), and Wu (2003)—examine the short-window market reaction around announcements of various types of earnings restatements, reporting that the mean and median reactions to such restatements are significantly negative. For example, Wu documents a threeday mean cumulative abnormal return of $-11.2 \% .{ }^{7} \mathrm{Wu}$ also reports a significantly negative return drift beginning at least 169 trading days prior to the restatement announcement, as well as a post-announcement negative return drift ending at least 85 days after announcement. These three studies report that the market reaction is significantly positively associated with the magnitude of the restatement, and that the market reaction is significantly more negative for cases which involve revenue, core earnings, or admissions of fraud than for other restatements. ${ }^{8}$ $\mathrm{Wu}$ (2003) reports that the market reaction is significantly more negative for restatements in which the amount of the restatement is not disclosed at the initial announcement and significantly less negative for restatements enforced by the SEC, ${ }^{9}$ whereas PRS report that the market reaction is significantly more negative for restatements enforced by the firm's auditor than for other restatements.

Of the studies investigating the market reaction to earnings restatements, only PRS (2004) examine a variable that captures an effect of the restatement on the history of earnings, which is our primary concern. PRS examine the number of past years of earnings that are restated, but find that this variable is insignificantly associated with returns. ${ }^{10}$

Researchers also examine the association of earnings restatements with other capital market, analyst forecast, and managerial compensation variables, documenting the pervasive effects of restatements. ${ }^{11}$ Specifically, Anderson and Yohn (2002) and Wu (2003) report that earnings restatements lead to a decline in regression-derived earnings response coefficients, 
Hribar and Jenkins (2004) find that restatements trigger increases in cost of capital, and Kravet and Shevlin (2006) report that restatements yield an increased factor loading on information risk in pricing models; all of these studies suggest that restatements increase investors' uncertainty. Palmrose et al. (2004) and Hribar and Jenkins (2004) document that restatements lead to significant decreases in analyst earnings forecasts and in the dispersion of the forecasts, and Griffin (2003) reports that informed investors, such as corporate insiders, short sellers, and institutional investors, sell stock prior to earnings restatements. ${ }^{12}$ Agrawal and Chadha (2004) report that earnings restatements are more likely when the CEO belongs to the founding family and less likely for firms whose boards or audit committees have an independent director with financial expertise. Burns and Kedia (2004) report that restatements are particularly large for firms where the CEO’s options portfolio is sensitive to stock price. Finally, Kedia and Philippon (2006) find that restatements are preceded by a period of excessive investment, employee hiring, and managerial exercise of options, and are followed by sharp disinvestments and employee firing. Desai et al. (2006) add that restatements lead to managerial turnover.

Palmrose and Scholz (2004) examine the association of restatements with the filing of class action lawsuits, and report that the probability of a lawsuit increases for restatements that involve core earnings, impact a large number of financial accounts, or are the result of fraud. ${ }^{13}$ They further report that the probability of a lawsuit is positively associated with the magnitude of the restatement, as well as with firm size, a recent initial public offering, prior sales growth, and the market reaction to the restatement announcement.

Three recent earnings restatement studies examine various aspects of either the historical record of originally reported earnings or the revision of that record—our focus of analysis. First, PRS find that the number of years restated is not associated with the market reaction to the 
announcement. Second, Richardson et al. (2003) report that restating firms are more likely to have attempted to maintain a string of consecutive quarters of earnings growth and positive earnings surprises prior to the restatement than non-restating firms. This finding bears directly on the motivation and structure of our study, with an important difference; Richardson et al. focus on the original series of pre-restatement earnings, while we focus on the impact of the restatement on the historical record (eliminating a pattern of earnings growth or positive earnings). A restatement following earnings growth or positive earnings patterns may, or may not, reverse those patterns. In fact, a substantial number of restatements in our sample (14\%) had a positive effect on prior earnings, thereby enhancing previously published growth patterns. So, there is a significant difference between the consideration of trends and patterns in the originallyreported earnings, and our focus on disruptions in those patterns. The third related study is Callen et al. (2003), who report that firms with histories of losses and a high likelihood of future losses are more likely to manipulate and subsequently restate revenues than are profitable firms. While Callen et al.'s findings imply that the history of earnings has a role in the occurrence and nature of restatements, their examination is restricted to loss firms for which revenues are substantially more value-relevant than earnings. In contrast, our study examines the broad sample of firms restating earnings.

Thus, while the historical record of earnings for restating firms has received some research attention, our main contribution lies in the sharp focus on the effect of restatements that significantly change the pattern of historical earnings—-that eliminate previously reported earnings growth or positive earnings—on returns to investors and the probability of a lawsuit. 


\section{Research on the Relevance of the Historical Record of Earnings}

The second strand of research relevant to our study is the work on the impact of the historical record on the information content of earnings. This research has three dimensions. First, Antle et al. (1994) show analytically that the information content of earnings, measured in terms of its association with contemporaneous returns, depends on the history of earnings and other variables when earnings either complement or substitute for the historical variables. Relatedly, they show that the full information content of earnings need not be manifested immediately, but may require future complementary information to be revealed in order to unlock the information conveyed by earnings.

Second, Lundholm (2003) constructs a model in which information on the ex post accuracy of prior accrual estimates motivates credible voluntary disclosures and thereby enriches the overall information environment. This provides theoretical support for Lundholm's (1999) proposal to require managers to routinely report on the comparison of estimates underlying financial information with subsequent realizations, creating ex ante disincentives to manipulate estimates. Other researchers have proposed that firms be required either to disclose or to restate past financial statements for revisions of major accrual estimates in order to provide better information about firm risk (Ryan 1997) and to curb earnings manipulation (Lev 2003). In this study, we provide empirical support for these proposals by demonstrating the relevance to investors and other users of financial reports of revisions of the historical record of earnings.

Lastly, Barth et al. (1999) document that the market applies higher pricing multiples to the earnings of firms with persistent histories of earnings growth. Relatedly, Barth et al. (1999), Myers and Skinner (2002), and Skinner and Sloan (2002) find that earnings multiples, market values, and stock returns of growth companies are more adversely affected by an earnings 
disappointment than are returns of no-growth firms. These findings indicating the relevance of the historical record of earnings to the interpretation of current information also motivate our following hypotheses.

\section{HYPOTHESES AND EMPIRICAL MODELS}

We hypothesize that earnings restatements that significantly change the historical pattern of earnings by eliminating or shortening histories of consecutive positive earnings or of earnings growth have more adverse consequences for investors (as reflected in stock returns) than do other restatements, and that such history-changing restatements increase the likelihood of class action lawsuits filed against the restating firms. We chose stock returns and the filing of class action lawsuits as dependent variables because they are major consequences of financial reporting, and they constitute the primary decision-oriented variables examined in the restatements literature.

We note here an issue that arises in making and testing these hypotheses. The impact of pattern-changing restatements on stock returns (and indirectly on lawsuits) depends on the statistical properties of the originally reported and restated earnings numbers, and, on what the market knows about these properties. For example, if both originally reported and restated earnings are known to follow a random walk, then the historical pattern of earnings will not affect stock returns after controlling for the levels of originally reported and restated current earnings. However, given the extreme circumstances of earnings restatements and the often troubled nature of restating firms, we do not expect either the originally reported or restated earnings to follow a random walk. ${ }^{14}$ 
The structure of our primary empirical models is as follows. In the stock returns model we regress (using pooled OLS estimation) beta-adjusted returns for the three-day window around the restatement announcement on: (a) indicator variables for restatements that eliminate or shorten histories of consecutive years of positive earnings or of earnings growth, (b) an indicator variable for restatements that affect the current year's earnings (prior research does not distinguish these restatements from those that affect only prior years' earnings), (c) the magnitudes of the effects of the restatement on current year's earnings and on earnings in all prior years combined (prior research examines the sum of these variables), and (d) various indicator variables for attributes of restatements and restating firms that prior research has found to be significantly associated with announcement returns. We thus separate in the returns tests the effects of the restatement on the historical pattern of earnings from the restatement's effects on current earnings. In the class action lawsuit analysis, we regress (using pooled logit estimation) an indicator variable for the filing of a class action lawsuit following a restatement on the explanatory variables used in the returns analysis as well as on stock returns contemporaneous with the restatement announcement as in Palmrose and Scholz (2004), and on returns prior to the restatement announcement.

\section{SAMPLe, VARIAbLES, AND Descriptive STATISTICS}

Our sample consists of 1032 earnings restatements reported in amended Form 10-Q/A (quarterly) or Form 10-K/A (annual) filed by U.S.-listed firms during 1977-2002. ${ }^{15}$ The sample is based on a detailed search of the LexisNexis Business, Dow Jones Interactive Publications Library, and ABI/Inform databases, using the keywords "restatement," "restate," "restated," "restates," and "restating.” The sample does not include restatements due to stock splits or 
dividends, discontinued operations, mergers and acquisitions, changes of accounting periods, and applications of new accounting principles or policies. As reported in Table 1, Panel A, from this initial sample we drop 19 observations that do not have identifying information, such as a perm number, cusip, or cnum, along with an additional 127 observations that are not on CRSP or are missing required CRSP data, and an additional 65 observations that are not on Compustat or are missing Compustat data. This yields our final sample of 821 restatements made by 750 distinct firms. We analyze this set of restatements below.

Of the 750 distinct firms, 64 have two restatements, three firms have three restatements, and one has four restatements in our original sample of 1032 restatements, although two of these multiple-restatement observations do not survive to the ultimate sample of 821 restatements. We do not distinguish single- and multiple-restatement observations in the tabulated analyses, although in untabulated analyses we observed no significant differences between these types of observations, as discussed with the other specification analyses in Sections VI and VII.

Our data include the date of the initial public announcement of a restatement and the date of the initial disclosure of the amounts of the restatement; the latter date may be the same as or follow the former date. Consistent with prior research, we examine only the market reaction around the restatement announcement. For each reporting period affected by the restatement, we obtained the amounts of the originally reported earnings and the restated earnings, defining the difference (restated minus originally reported) as the amount of the restatement for that period. The indicator variable nonumbers takes a value of one for restatements whose amounts are not disclosed at the initial announcement (and, as for all other dichotomous indicator variables, a value of zero otherwise). Consistent with Wu's (2003) findings, we expect restatement announcements that do not disclose the amount of the restatement to have more adverse 
implications for investors (in part due to larger uncertainty) than restatement announcements with the amount indicated. As reported in Table 2, Panel A, there are 269 observations in the sample for which nonumbers takes a value of one, constituting 33\% of the observations. Also reported in Table 1, Panel A, the amount of the restatement is never disclosed for six observations ( $1 \%$ of the sample), in which case we set this amount to zero rather than eliminate the observation; this has no substantive effect on our results. As evident in Wu (2003) and reported in our Table 1, Panel B, the frequency of earnings restatements has risen over time, with 453 (55\%) of the observations occurring in the last five years of the 26 -year sample period. ${ }^{16}$ Earnings restatements may pertain to relatively recent or to further lagged fiscal periods, or to both time frames. Prior research has not distinguished restatements along this dimension, but we do so because we are concerned with how restatements affect the historical record of earnings. We distinguish restatements which are announced no later than four months after the end of the last fiscal year restated, termed “current restatements,” from restatements announced more than four months after the end of the last fiscal year restated, termed "lagged restatements." The reason for this distinction is to examine whether investors and analysts treat restatements of the current year's earnings that are announced within the normal annual financial reporting period differently from late restatements. It is often alleged that investors and analysts focus excessively on current earnings, and thus these users may view late restatements as stale, As reported in Table 2, Panels A and B, 661 (81\%) restatements are current and 160 (19\%) are lagged; of the lagged restatements, 143 (17\%) are disclosed up to one year after the threshold (four months after the end of the fiscal year of the most recent restated period) and 17 (2\%) are announced more than one year after this threshold. We indicate current and lagged restatements by the dichotomous variables current and lagged, respectively. 
Prior research has analyzed the total amount of the restatement across the restated fiscal periods, which we denote by mag (for magnitude). In contrast with prior studies, we decompose mag into the amount of current restatement related to the most recent fiscal year restated, denoted by currentmag, and the amount related to all preceding periods, denoted by laggedmag. That is, laggedmag includes the lagged portion of current restatements and the total amount of lagged restatements. (These two components of laggedmag are effectively separated in our empirical analyses of the current and lagged restatement subsamples discussed in Section V.) ${ }^{17}$ Mag equals the sum of currentmag and laggedmag.

The following hypothetical example clarifies these definitions. Suppose a calendar year firm announces the following restatement of earnings on July 30, 1998: Earnings for the first two quarters of 1998 are reduced by $\$ 100$, and earnings for 1997 and 1996 are reduced by $\$ 300$ and $\$ 50$, respectively. In this example, the restatement is current (announced before the end of the current fiscal year); the variable currentmag is $-\$ 100$, laggedmag is $-\$ 350$ (the sum of $-\$ 300$ and $-\$ 50$ ), and mag (total restatement) is $-\$ 450$ (the sum of $-\$ 100$ and $-\$ 350$ ). While both currentmag and laggedmag are revisions of historical figures, the former relates to current year's earnings history, while the latter relates to the lagged historical record of earnings.

Prior research has shown that mag is positively associated with the restatement announcement return, and we expect this association to hold for both our currentmag and laggedmag. Surprisingly, Palmrose and Scholz (2004) find that mag is positively associated with the likelihood that a class action lawsuit is filed (recall, positive mag is an earnings increase), and accordingly we do not make a prediction about the effect of currentmag or laggedmag on that likelihood. 
Currentmag, laggedmag, and mag are each deflated by market capitalization of the firm at the beginning of the three-day (day before to day after) restatement announcement return window. As reported in Table 2, Panel D, currentmag, laggedmag, and mag have negative means (earnings reducting) of $-0.034,-0.030$, and -0.065 , respectively. Of the total sample, 619 (75\%) of the restatements involve net reductions of cumulative earnings (negative $\mathrm{mag}$ ), and 119 (14\%) involve net increases in cumulative earnings (positive mag). The remaining 83 (10\%) of the restatements have zero effect on cumulative earnings (zero mag). Of these 83 restatements, eight involve perfectly offsetting effects on currentmag and laggedmag, 69 involve perfectly offsetting effects on earnings for fiscal periods within the time period reflected in either or both of currentmag or laggedmag, and six involve restatements for which the amount was never disclosed.

Our primary test variables reflect the effect of the restatement on the histories of earnings growth and positive earnings. The fact that the sample restatements differ in terms of the specific periods restated, involving various combinations of fiscal quarters and years, complicates our ability to quantify the effects on prior patterns in a comparable manner across firms. For simplicity, we analyze only the effect of restatements on the history of annual earnings, with the exception of the most recent fiscal year restated when it does not involve a complete year. For the latter, we define the most recent fiscal year as the portion of the year up to the most recent fiscal quarter restated. ${ }^{18}$ We make this exception to avoid a look-ahead bias.

Our primary measures of the effects of a restatement on the history of earnings are two indicator variables: (a) undoearngrow, which takes a value of one for firms that prior to the restatement had a continuous history of positive annual earnings growth (in dollar terms) of one or more years which was eliminated or shortened by the restatement; and (b) undoearnpos, 
which takes a value of one for firms that prior to the restatement had a continuous history of positive annual earnings for one or more years which was eliminated or shortened by the restatement. ${ }^{19}$ We expect the market effect of restatements to be more negative and pronounced when either undoearngrow or undoearnpos takes a value of one, all else equal. As reported in Table 2, Panels A and C, undoearngrow takes a value of one for 96 observations (12\% of the sample), which is slightly more than a quarter of the 362 (44\%) observations with a history of earnings growth in our sample. Undoearnpos takes a value of one for 153 (19\%) observations, which is slightly less than a third of the 485 (59\%) observations with a history of positive earnings. $^{20}$ The relatively low percentages of the sample observations with a history of earnings growth (44\%) or of positive earnings (59\%) indicate the prior spotty performance of many restating firms, documented by Kinney and McDaniel (1989).

As indicated above, for current restatements we define the current year as the first quarter of the year up to the most recent quarter restated, which can be less than four quarters. This definition affects undoearngrow because it will typically be more difficult for a firm to have reported a history of earnings growth if a restatement occurs early in the fiscal year (i.e., the most recent period is less than a year). Reflecting this fact, 74 (77\%) of the 96 restatements for which undoearngrow takes a value of one involve either three-quarters or all of the most recent fiscal year, despite the fact that restatements are spread fairly evenly across the fiscal quarters of the most recent fiscal year. This definition does not have a similarly significant effect on undoearnpos, the elimination of a positive earnings history, however.

In specification analysis, we examine two additional indicator variables related to the length of the history of earnings growth or positive earnings, using a dividing line of four years to distinguish firms with longer from those with shorter histories: grow4 takes a value of one for 
firms with a four-year or longer history of earnings growth affected by the restatement, and pos 4 takes a value of one for firms with a four-year or longer history of positive earnings affected by the restatement. ${ }^{21}$ We have 32 observations with grow $4=1$, and 243 observations with pos $4=1$. Consistent with the findings of Barth et al. (1999), Myers and Skinner (2002), and Skinner and Sloan (2002) discussed in Section III, we expect a harsher impact on returns from a restatement that eliminates or shortens a history of past earnings growth (undoearngrow $=1$ ) if grow 4 also takes a value of one. Similarly, we expect a restatement that eliminates or shortens a history of positive earnings (undoearnpos $=1$ ) to have more negative returns implications if pos 4 also takes a value of one. Finally, the joint variable undoearngrowpos takes a value of one (for 201 observations) for firms with either undoearngrow or undoearnpos equaling one.

We also include in the analysis the following variables that prior research by Palmrose et al. (2004), Anderson and Yohn (2002), and Wu (2003) (PRS, AY, and Wu, respectively) finds to be significantly related to the market reaction to restatement announcements: An indicator variable, revenue, for restatements that involve revenue recognition ${ }^{22}$-we expect such restatements to have more adverse return implications than other restatements—and indicator variables for restatements required by the SEC (SEC) or those that the firm admitted fraud (fraud). Consistent with prior findings, we expect restatements required by the SEC to have less adverse implications and those involving fraud more adverse implications than other restatements. As reported in Table 2, Panel A, revenue takes a value of one for 334 (41\%) observations, SEC takes a value of one for 193 (24\%) observations, and fraud takes a value of one for $92(12 \%)$ observations.

We obtained from the CRSP database daily raw, beta-adjusted, and size-adjusted returns as well as market capitalizations at the beginning of the return window. Reflecting our short 
return window, all of our results are virtually identical irrespective of the return measure used, and accordingly we report below only results for beta-adjusted returns. Buy-and-hold betaadjusted returns for the three-day window around the restatement announcement are denoted by $R_{-1,1}$.

Table 2, Panel E, reports Pearson correlations for the variables used in the primary returns analysis. The correlations of the announcement period return with the variables examined in prior research are all consistent with the results of that research: $R_{-1,1}$ (the announcement period return) is significantly negatively correlated with revenue (restatements involving revenue recognition), nonumbers (restatements reported without amounts), and fraud (restatements of firms admitting fraud), and is significantly positively correlated with SEC (SEC-initiated restatements). The correlations are also consistent with our hypotheses regarding the main test variables, with $R_{-1,1}$ being significantly negatively correlated with undoearngrow and undoearnpos (pattern-disrupting restatements). As expected, $R_{-1,1}$ is significantly positively correlated with mag (total magnitude of restatement across periods) and currentmag. Unexpectedly, although consistent with investors and analysts viewing restatements of lagged earnings as stale, $R_{-1,1}$ is insignificantly correlated with laggedmag. While we made no predictions in this regard, $R_{-1,1}$ is significantly negatively correlated with current (restatements announced within four months after the end of the fiscal year of the most recent restated period).

Our main test variables, undoearngrow and undoearnpos (eliminating or shortening histories of earnings growth or positive earnings, respectively), are significantly correlated with many of the other explanatory variables. The signs of these correlations reflect the expected adverse implications for investors of these test variables taking the value of one. Specifically, both the primary variables are significantly negatively associated with mag and currentmag, and 
undoearnpos is also significantly negatively associated with laggedmag. Both variables are significantly positively associated with nonumbers and fraud. Undoearnpos is also significantly positively associated with revenue. The multivariate regressions reported next control for these explanatory variables and thus provide evidence on the incremental capital market implications of the primary test variables.

\section{Returns Analysis}

\section{Full Sample Analysis}

Reflecting the discussion in Sections IV and V, our primary returns models are all nested within the following equation:

$$
\begin{aligned}
R_{-1,+1}=\alpha & +\alpha_{c} \text { current }+\beta \text { mag }+\beta_{c} \text { currentmag }+\beta_{l} \text { laggedmag }+\gamma_{g} \text { undoearngrow } \\
& +\gamma_{p} \text { undoearnpos }+\delta_{r} \text { revenue }+\delta_{n} \text { nonumbers }+\delta_{s} S E C+\delta_{f} \text { fraud } .
\end{aligned}
$$

Equation (1) embodies two essential extensions of the empirical models used in the prior literature. First, it allows us to examine the relevance of our primary test variables, undoearngrow and undoearnpos, by excluding or including them in the analysis. Based on the hypotheses stated in Section IV, we expect the coefficients on these two variables to be negative. Second, equation (1) allows us to examine the relevance of the distinction between the current and lagged components of mag (the total magnitude of restatements) by including in the equation either mag alone or the variables current, currentmag, and laggedmag together. As discussed in Section V, we expect the regression intercept (which captures the average capital market reaction to lagged restatements when current is included in the model and to all restatements otherwise) to be negative. We do not have expectations for the coefficient on current (which captures the 
incremental average market reaction to current restatements), and we expect the coefficients on currentmag, laggedmag, and mag to be positive.

Based on the prior research summarized in Section III, we expect the intercept and the coefficients on revenue, nonumbers, and fraud in equation (1) to be negative, and the coefficients on $m a g$ and $S E C$ to be positive. When our expectations for coefficients are directional (nondirectional), unless indicated otherwise, we say a coefficient is significant if the $t$ statistic is significantly different from zero at the $5 \%$ level in a one-tailed (two-tailed) test.

Table 3 reports the pooled OLS estimation of three models nested within equation (1). The left column reports the estimates of a model that corresponds to the significant variables reported in the prior literature; this model excludes the variables current, currentmag, laggedmag, undoearngrow, and undoearnpos. Consistent with that literature, the intercept is significantly negative $(t=-5.9)$, the coefficient on $m a g$ is significantly positive $(t=2.1)$, the coefficients on revenue $(t=-4.4)$, nonumbers $(t=-6.9)$, and fraud $(t=-4.4)$ are significantly negative, and the coefficient on $S E C$ is significantly positive $(t=3.7)$. The model's adjusted $R^{2}$ is 17.4\%. Thus, the total magnitude of restatements across years affects returns in the predicted direction. Furthermore, returns are more negative when restatements involve revenue recognition, are announced without amounts, or involve fraud, and are more positive when restatements are initiated by the SEC.

The middle column of Table 3 reports the results of decomposing mag into its timeliness components, currentmag and laggedmag, and adding the indicator variable current, but otherwise maintaining the same model as in the left column of the table. As expected, the intercept (average market reaction to lagged restatements) is significantly negative ( $\mathrm{t}=-3.0)$. The coefficient on current (average incremental reaction to current restatements) is insignificantly 
negative. Also as expected, the coefficient on currentmag is significantly positive $(t=3.4)$; it is also significantly more positive at the $10 \%$ level than the coefficient on mag in the model reported in the left column $(t=1.6)$. Note that the insignificant coefficient on laggedmag does not imply that lagged restatements have no capital market implications. They indeed do, as indicated by the subsample analysis that follows. The coefficients on the variables common to the models in the left two columns of Table 3 are virtually identical, although the significance of the intercept is noticeably lower in the middle column, reflecting the additional explanatory power obtained by decomposing mag into its currentmag and laggedmag components. The model $R^{2}$ rises from $17.4 \%$ to $18.4 \%$, implying that it is important to distinguish between the magnitudes of the current and lagged components of restatements.

The right column of Table 3 reports the results of adding to the model the primary pattern-disruption test variables undoearngrow and undoearnpos. As expected, the coefficient on undoearngrow is significantly negative $(t=-2.8)$, as is the coefficient on undoearnpos $(t=-2.5)$. The coefficients on the variables common to the models in the middle and right columns retain the same signs and yield the same conclusions with respect to significance across the models, although the inclusion of the primary test variables noticeably reduces the significance of the intercept and the coefficients on currentmag and nonumbers. The model's $R^{2}$ rises to $20.2 \%$. These results indicate that changes in the history of earnings growth or positive earnings brought about by the restatement—-the focus of our analysis—do affect investors' decisions.

\section{Subsample Analysis}

Table 4 reports estimates of the model in the right column of Table 3 (to the extent the independent variables vary) for two subsamples of observations: (1) current versus lagged 
restatements, and (2) restatements involving admitted fraud versus other restatements. The first subsample is examined to determine whether there are significant differences between current and lagged restatements, consistent with our focus on the implications of restatements on the historical record of earnings. An additional insight of this analysis is that it distinguishes the implications of the two components of laggedmag: the lagged portion of current restatements and all of lagged restatements. The second subsample is examined to determine whether our overall results are driven by the extreme observations of admitted fraud, or that the results are also valid for the non-fraud restatements. To the extent that our results are attributable in whole or part to non-fraud observations, they can be generalized to other revisions of accrual estimates.

Note that current cannot be included in either the current or lagged subsample analysis and, in addition, currentmag cannot be included in the lagged subsample analysis due to no variation of these variables across the observations. Similarly, fraud cannot be included in the model for the fraud subsamples. The coefficient differences between each pair of subsamples and the associated $t$ statistics are reported in Table 4. A limitation of these analyses is that the lagged restatement and fraud subsamples are relatively small at 160 and 92 observations, respectively, reducing the power of the tests of coefficients for these subsamples and of differences of coefficients across the subsamples.

The first and second columns (from left) of Table 4 reports the results for the current and lagged restatement subsamples, respectively, with the third column reporting differences in the coefficients across the two subsamples. The estimates for the current restatement subsample are quite similar to those for the overall sample in the right column of Table 3, although the coefficient on laggedmag is insignificantly positive rather than insignificantly negative. The reason for this difference is apparent in the results for the lagged restatement subsample, for 
which the coefficient on laggedmag is significantly negative at the $10 \%$ level. The difference between the coefficients on laggedmag in the current and lagged subsamples is significantly positive at the $10 \%$ level $(\mathrm{t}=1.4)$. This suggests that the market reacts differently to the magnitude of lagged restatements (announced more than four months after last fiscal-year end) than to the magnitude of the lagged portion of current restatements. Conceivably, this difference may be attributable to the reversing property of accruals discussed in Section IV.$^{23}$ Since by construction lagged restatements have no (reversing) effect on current earnings, these restatements may be more likely to reverse in future earnings, compared to the lagged portion of current restatements.

A number of the other coefficients are noticeably different for the current and lagged restatements subsamples, although only the difference of the coefficients on $S E C$ is significant at the usual level ( $\mathrm{t}=2.1$ ). Specifically, unlike the significantly positive coefficient on $S E C$ in the current restatement subsample, the coefficient on $S E C$ is close to zero and insignificant in the lagged restatement subsample. This difference is probably attributable to current SEC restatements being more likely to reflect a recently arisen accounting issue applying to many firms (e.g., in-process research and development), whereas lagged SEC restatements being more likely to be firm specific. The coefficients on fraud and nonumbers also are more negative in the lagged restatement subsample, suggesting that some of these restatements involve systematic financial reporting problems that went undiscovered for a period of time and so take time to investigate. In contrast, the intercept and coefficient on revenue are less negative, suggesting that on average lagged restatements are less adverse. The coefficients on undoearngrow and undoearnpos—our primary variables—are quite similar across the two subsamples, suggesting 
the impact of a restatement on the historical pattern of earnings is important regardless of the type of restatement.

The fourth and fifth columns (from left) of Table 4 report the results for the fraud and nofraud subsamples, respectively, with the right column reporting differences in the coefficients across the two subsamples. As indicated by the significantly more negative intercept in the fraud than no-fraud subsample ( $\mathrm{t}=-2.5)$, restatements involving admitted fraud have considerably more adverse implications for investors than no-fraud restatements. Perhaps reflecting the small size of the fraud sample, the only coefficient that is significant in the fraud subsample is nonumbers $(t=-2.3)$. The results for the no-fraud subsample are quite similar to those for the overall sample in the right column of Table 3. So, our findings regarding pattern-disrupting restatements are not driven by those involving fraud. Aside from the difference of the intercepts just mentioned, none of the coefficient differences across the fraud and no-fraud subsamples are significant.

\section{Specification Analysis}

In Table 5, we report the results of supplemental analyses that arise from the following variant of equation (1):

$$
\begin{aligned}
R_{1,+1}=\alpha & +\alpha_{c} \text { current }+\beta_{c} \text { currentmag }+\beta_{l} \text { laggedmag }+\gamma_{g} \text { undoearngrow } \\
& +\gamma_{g 4}(\text { undoearngrow } \times \text { grow } 4)+\gamma_{p} \text { undoearnpos }+\gamma_{p 4}(\text { undoearnpos } \times \text { pos } 4)+ \\
& +\gamma_{g p} \text { undoearngrowpos }+\delta_{r} \text { revenue }+\delta_{n} \text { nonumbers }+\delta_{s} S E C+\delta_{f} \text { fraud } .
\end{aligned}
$$

Equation (2) allows us to examine the importance of interacting longer histories of earnings growth (grow4) or positive earnings (pos4) with the primary test variables undoearngrow and undoearnpos. We expect the coefficients on both undoearngrow $\times$ grow 4 and undoearnpos $\times$ pos 4 to be negative, implying a more pronounced adverse investor reaction when the restatement 
eliminates or shortens a lengthy, persistent string of earnings growth or positive earnings relative to the effect of undoing shorter histories. Equation (2) also allows us to examine how much if any explanatory power is lost by replacing undoearngrow and undoearnpos with undoearngrowpos (a single variable that indicates restatements that undo histories of either earnings growth or positive earnings). We expect a negative coefficient on undoearngrowpos.

The left column of Table 5 reports the estimates of the model adding undoearngrow $\times$ grow 4 and undoearnpos $\times$ pos 4 to the model in the right column of Table 3 (i.e., progressing from equation (1) to equation (2)). As expected, the coefficient on undoearngrow $\times$ grow 4 is significantly negative $(t=-2.1)$, consistent with a harsher investor reaction to eliminating or shortening a long history of earnings growth. Unexpectedly, however, the coefficient on undoearnpos $\times$ pos 4 is significantly positive $(t=2.8)$; moreover, this coefficient almost perfectly offsets the negative coefficient on undoearnpos. This coefficient sign is inconsistent with the expected adverse implications from the elimination or shortening of a long string of positive earnings. We conjecture that this result arises from the proxy role of pos 4 for the solvency of the firm, consistent with prior research which shows that positive earnings correlate with positive cash flows and other solvency indicators. ${ }^{24}$ The coefficients on the other variables in this model closely mirror those in the right column of Table 3, although the significance of the intercept continues to diminish. The model's $R^{2}$ rises by $0.9 \%$ to $21.1 \%$ compared to the model in the third column of Table 3. These results imply that it is important to consider the length of the history of earnings growth or positive earnings that is eliminated or shortened by a restatement.

The right column of Table 5 reports the results of replacing undoearngrow and undoearnpos with undoearngrowpos. In this model, undoearngrowpos is significantly negative $(t=-4.2)$, and the model $R^{2}$ falls by only $0.1 \%$ to $20.1 \%$, compared to the model in the right column of Table 3 , 
implying that little information is lost by replacing undoearngrow and undoearnpos with undoearngrowpos.

In untabulated robustness analyses we added the following control variables to the returns models (1) and (2): market capitalization, number of years restated, indicator variables for whether there were prior restatements by the same firm anytime in our sample period or in the prior three years, indicator variables for whether prior restatements gave rise to lawsuits or were SEC-enforced, prior six-month buy-and-hold beta-adjusted return (momentum), an indicator variable for confounding events in the restatement announcement window, an indicator variable for whether the restatement involved a 10-K filing or just 10-Q filings, and an institutional ownership measure specified as either a percentage of ownership or as a high versus low indicator variable. None of these variables was statistically significant, and none exerted a significant effect on the primary variables.

\section{Class ACtion Lawsuit Analysis}

\section{Descriptive Statistics}

The indicator variable lawsuit takes a value of one if a class action lawsuit was filed as a result of the restatement (generally very shortly afterwards). As reported in Table 6, Panel A, lawsuit takes a value of one for 211 observations, amounting to $26 \%$ of the sample. Panel A also reports counts of indicator variables for the subsamples of no-lawsuit and lawsuit observations, with $\chi^{2}$ test statistics for differences in these counts across the subsamples. These counts indicate that the lawsuit subsample clearly involves significantly more value-decreasing restatements than does the no-lawsuit subsample, is significantly more likely to have undoearngrow, undoearnpos, 
revenue, nonumbers, and fraud take values of one, and to have $S E C$ take a value of zero than the no-lawsuit subsample.

Furthermore, Table 6, Panel B reports the means and medians of the continuous variables, with corresponding $t$ and $\chi^{2}$ test statistics, indicating similar effects for the lawsuit and no-lawsuit subsamples. Compared to the no-lawsuit subsample, the lawsuit subsample has substantially more negative mag (total restatement magnitude), $R_{-1,1}$ (the restatement announcement period mean return is $-5.7 \%$ for the no-lawsuit group and $-25.0 \%$ for the lawsuit group), and buy-and-hold beta-adjusted return for the six months preceding the restatement announcement $\left(R_{-127,-2}\right)$. This is consistent with the general evidence on investor lawsuits indicating that a large price drop upon the announcement of an adverse event is a necessary (though not sufficient) condition for a lawsuit (e.g., Lu, 2003). Similar effects are indicated by the Pearson correlations of lawsuit with the other variables, reported in Table 6, Panel C: Lawsuit is significantly positively correlated with undoearngrow, undoearnpos, revenue, nonumbers, and fraud, and it is significantly negatively correlated with currentmag, $S E C, R_{-1,1}$, and $R_{-127,-2}$.

\section{Full Sample Analysis}

Building on the discussion in Sections IV and V, our class action lawsuit models are nested within the following equation:

$$
\begin{aligned}
\text { lawsuit }= & \alpha+\alpha_{c} \text { current }+\beta_{c} \text { currentmag }+\beta_{l} \text { laggedmag }+\gamma_{g} \text { undoearngrow } \\
& +\gamma_{p} \text { undoearnpos }+\delta_{r} \text { revenue }+\delta_{n} \text { nonumbers }+\delta_{s} S E C+\delta_{f} \text { fraud } \\
& +\phi_{\text {ann }} R_{1,+1}+\phi_{\text {pre }} R_{127,2} .
\end{aligned}
$$


Equation (3) regresses the dichotomous variable lawsuit on the set of explanatory variables present in the returns model (1) and reported in the right column of Table 3, with the addition of the returns variables $R_{-1,1}$ and $R_{-127,-2}$. Palmrose and Scholz (2004) report that the short-window restatement announcement return has a significantly negative coefficient, consistent with the announcement return reflecting the severity of the restatement and class action lawyers' incentives to file lawsuits. We add to the model the return during six months prior to the restatement announcement, as it is likely to capture news about the restatement leaking out before disclosure, and we accordingly expect this return to have a negative coefficient in relation to the likelihood of lawsuit.

We expect the coefficients on the remaining variables in equation (3) to have the opposite sign they had in the returns analysis; that is, we expect the coefficients on undoearngrow, undoearnpos, revenue, nonumbers, and fraud to be positive, and the coefficient on SEC to be negative. However, because Palmrose and Scholz (2004) report a somewhat puzzling positive coefficient on mag, we do not predict the sign of currentmag and laggedmag, despite the positive coefficient on currentmag in the returns analysis. ${ }^{25}$

Table 7 reports the pooled estimation of equation (3), both including and excluding the returns variables, since these variables are likely to subsume some of the effects of the other explanatory variables. Because the dependent variable lawsuit is binary, we primarily estimate equation (3) using a logit estimation, although for comparison purposes and to provide an $\mathrm{R}^{2}$ estimate we also report the results of an OLS estimation. Table 7 also reports the marginal effects of the explanatory variables on the probability of a lawsuit implied by the coefficients from the logit estimation when these variables increase by one. 
The second column from the left in Table 7 reports the logit estimation of equation (3), excluding the returns variables. As expected, the coefficient on the primary test variable undoearngrow is significantly positive $(t=2.8)$, as is the coefficient on undoearnpos, though only at the $10 \%$ level $(t=1.3)$. Thus, eliminating or shortening a history of earnings growth or of positive earnings significantly raises the probability of a class action lawsuit being filed subsequent to a restatement. The marginal effect of undoearngrow taking a value of one on the probability of a class action lawsuit being filed is very substantial: $13.1 \%$. The coefficients on the control variables generally conform to expectations and/or to the returns results: the coefficients on current $(t=2.5)$, revenue $(t=4.2)$, nonumbers $(t=7.0)$, and fraud $(t=5.1)$ are significantly positive, although the coefficient on $S E C$ is insignificant. The marginal effects of the significant control variables on the probability of lawsuit are all substantial, ranging from $13.1 \%$ for revenue to $22.8 \%$ for fraud. The model classifies $78.3 \%$ of the observations correctly, which is a significant improvement over the naïve model which classifies all restatements as nolawsuits $\left(\chi^{2}=100.9\right)$. This latter model classifies $74.3 \%$ of the observations correctly.

In Table 7, the second from right column reports the logit estimation of equation (3) including the two returns variables (prior to and around the restatement announcement). Consistent with the findings of Palmrose and Scholz (2004), the coefficient on $R_{-1,1}$ is significantly negative $(t=-8.6)$, as is the coefficient and $R_{-127,-2}(t=-2.6)$. The variable $R_{-1,1}$ (the short-window announcement return) is a particularly powerful explanatory variable. Its inclusion in the model reduces the significance of the other explanatory variables, yet the coefficient on undoearngrow remains significantly positive $(t=2.0)$. The model classifies $81.8 \%$ of the observations correctly—a significant improvement over the naïve model which classifies all restatements as non-lawsuits—delivering only 74.3\% accuracy $\left(\chi^{2}=190.3\right)$. 
Table 8 provides information on the percentage of no-lawsuit and lawsuit observations classified correctly (equivalently, one minus the percentages of Type I and Type II errors under the null hypothesis of no lawsuit) by the logit estimation of equation (3) with the return variables included. Notably, the percentage of observations predicted correctly is considerably lower for lawsuits than for no-lawsuits. For example, 49.3\% of actual lawsuits are predicted as such (Type II error equal to 50.7\%), while $93.0 \%$ of the no-lawsuits are predicted as no-lawsuits (Type I error equal to $7.0 \%)$. This differential classification ability likely results from no-lawsuits being almost three times more common in the sample than lawsuits and from the logit estimation imposing the same loss for misclassifying lawsuits as no-lawsuits and no-lawsuits as lawsuits. To provide further insight, Table 8 presents detailed analysis of the percentages of actual lawsuit and no-lawsuit observations that are correctly predicted by equation (3) for the overall and postPSLRA samples, discussed in the next section. The second row of Table 8 indicates that the percentage of lawsuits that are correctly predicted as such is considerably higher for the postPSLRA sample: $61.2 \%$ vs. $49.3 \%$. These results are consistent with the conjecture (elaborated below) that class action litigation is increasingly accounting-driven following the passage of the PSLRA.

\section{Specification Analyses}

Since the existence of a prior class action lawsuit could affect the likelihood that a lawsuit was filed after the restatement, we conducted the following two specification analyses. First, we added indicator variables for whether the lawsuit preceded the restatement (one observation) or prior restatements gave rise to a lawsuit either anytime during our sample period (21 observations) or during the three years preceding the restatement under consideration (19 
observations). Second, we redefined the dependent variable to also take a value of one if a lawsuit preceded the restatement or was associated with a prior restatement, either anytime during our sample period or during the three years preceding the restatement under consideration. Neither of these analyses had significant effects on our results.

In addition, we conducted various untabulated robustness tests adding explanatory variables similar to those included in to the returns analysis discussed in Section VI. None of these variables was statistically significant or exerted a significant effect on the primary variables in the model.

\section{The Post-PSLRA Period}

Table 9 reports the analysis in Table 7, but for the subsample of 540 restatements announced after the passage of the Private Securities Litigation Reform Act (PSLRA) on December 22, 1995. Grundfest and Perino (1997) among others report that post-PSLRA, accounting issues drive a larger portion of shareholder litigation and settlements than in the prePSLRA era. It is therefore instructive to examine the effect of PSLRA on our restatements sample.

It is evident from Table 9 that the results of the lawsuit analysis for the post-PSLRA period are stronger in certain respects than those for the entire sample period. In particular, our test variables undoearngrow and undoearnpos are more significant in this subsample, and the model as a whole performs better in classifying observations compared to a naïve model (see also Table 8). We conjecture that this change reflects the effect of the increasingly accountingdriven nature of class action litigation following the passage of the PSLRA. 


\section{CONCLUding REMARKS}

We document in this study that earnings restatements informing about significant changes in the historical pattern of earnings — the elimination or shortening of previously reported records of earnings growth or positive earnings — significantly affect investors’ valuation of current financial data, and enhance the likelihood of class action lawsuits filed after the restatements. We control in our analysis for the effects of restatements on the magnitudes of current and lagged earnings, as well as for various attributes of restatements that the prior literature has found to be associated with investor reaction and the likelihood of class action lawsuits, and for a slew of other variables. Henry Ford is reputed to have said "history is more or less bunk.” Our empirical evidence on the relevance of rewriting earnings history dispels Ford's view, at least insofar as accounting information is concerned.

Our findings about the valuation-relevance of changes in historical patterns of earnings, along with prior research on the relevance of the historical record of financial information, raise an important question for accounting standards setters: Should a revision of the historical financial record be required when newly revealed information contradicts the assumptions/projections underlying previously disclosed financial data, or should revisions be restricted to mistakes or oversight that existed at the time the financial statements were prepared (APB20)? The issues involved in such an extension of the scope of restatements are, of course, complex. APB 20 makes a clear distinctive between “[e]rrors in financial statements [resulting from] oversight or misuse of facts that existed at the time the financial statements were prepared" — which call for a restatement—and a "change in accounting estimate [which] results from new information or subsequent developments”- which does not lead to a restatement (emphasis ours). However, in reality, the distinction between information which existed at the 
financial reporting time and new information is often blurred. Consider, for example, a deterioration in the financial conditions of a customer ignored in the most recent provision for uncollectible receivables. How can one objectively determine whether the customer's financial deterioration was knowable at the financial reporting time (and, therefore, warrants a restatement) or not? Perhaps, had the firm consulted a credit agency, or performed an elaborate solvency analysis, the subsequent financial deterioration of the customer could have been predicted, and thus necessitates a restatement. With the passage of time subsequent to the financial report release it becomes increasingly difficult to distinguish between information which was known, knowable, and unknowable (e.g., a hurricane) "at the time” the financial reports were prepared.

These difficulties obviously allow firms to interpret APB 20 narrowly, claiming that most inconsistencies between estimates and projections underlying financial reports and subsequent realizations were not known or knowable at the time the financial reports were prepared. Our evidence on the importance to investors of refreshing the historical financial record as well as the substantial increases in the number of restatements, and recent FASB pronouncements (e.g., FAS 154) emphasizing the relevance of intertemporal comparability and consistency of financial information, suggest that a reexamination of the circumstances calling for a restatement is warranted. 


\section{NOTES}

${ }^{1}$ There are a few other cases where firms are required to disclose revisions of historical records. For example, FAS 146 requires firms to disclose revisions of liabilities accrued for exit or disposal activities.

${ }^{2}$ This may be attributable in part to findings (e.g., Ball and Watts (1972)) that earnings tend to follow a random walk, although Brooks and Buckmaster (1980) report that this is not the case for firms with large absolute earnings changes. We discuss the issue of earnings following a random walk in more detail in Section IV.

${ }^{3}$ There are, of course, exceptions to this statement, such as Barth et al. (1999).

${ }^{4}$ For elaboration on the role of historical context in general in understanding and interpreting current events, see Howard (1991, Ch.1).

${ }^{5}$ See, for example, Mankiw and Shapiro (1986) and Diebold and Rudenbusch (1991).

${ }^{6}$ A literature similarly motivated to that of earnings restatements examines property-casualty insurers' loss reserve development disclosures. Under the Securities and Exchange Commission’s Exchange Act Industry Guide 4, property-casualty insurers are required annually to update prior estimates of their claim loss reserves for each prior accident year's coverage. This literature documents that loss reserves are estimated with discretion (e.g., loss reserve revisions are negatively correlated with insurer solvency and positively serially correlated), and that upward loss reserve revisions have negative implications for insurers' market value, risk, and future profitability. See Petroni (1992), Beaver and McNichols (1998,2001), and Petroni, Ryan, and Wahlen (2000).

${ }^{7}$ Feroz et al. (1991) and Dechow et al. (1996) find similar negative market reactions at the announcement of SEC enforcement actions. 
${ }^{8}$ In a specification test, PRS (2004) replace the magnitude of the restatement with an indicator variable for restatements that decrease current income and the absolute value of the change in net income; they find that the coefficients on both variables are significantly negative.

${ }^{9}$ While it may seem surprising that the market reacts less adversely to SEC-enforced earnings restatements, this finding presumably reflects the fact that these restatements often result from the SEC's desire to change a general accounting practices (e.g., in-process research and development) which affects multiple firms. To the extent that more firms make these restatements, they apparently reflect less negatively on any given restating firm.

${ }^{10}$ PRS (2004), AY (2002), and Wu (2003) include numerous control variables in their returns regression models which they find (and in supplemental analysis we confirm) to be insignificant. Of particular note, Wu finds that the coefficient on an indicator variable for confounding significant disclosures or events in the restatement announcement window is insignificantly negative.

${ }^{11}$ Dechow et al. (1996) conduct similar analyses and obtain similar findings for SEC enforcement actions.

${ }^{12}$ Summers and Sweeney (1998) document similar stock sales by insiders prior to the revelation of fraud, as does Beneish (1999) prior to SEC enforcement actions.

${ }^{13}$ Bonner et al. (1998) obtain similar results for the filing of lawsuits against the auditors of firms subject to SEC enforcement actions.

${ }^{14}$ A related issue is that restatements of earnings, like all accrual adjustments, reverse over time. Sometimes these reversals are complete when restatements are announced (restatements that decrease earnings in certain periods, and increase earnings by the same amount in other periods), and sometimes they are incomplete (e.g., restatements that only decrease earnings prior to 
announcement). Whether these reversals are complete or not has implications for the prediction of future earnings and so may affect returns or the likelihood of class action lawsuits differently (e.g., investors may not be fully aware of the future reversals in the second type of restatements, above). We do not explore this issue.

${ }^{15}$ Most of this sample was collected by Wu (2003), excluding her restatements of previously announced unofficial results. We extended her sample forward in time by collecting 83 additional restatements in 2001 and 2002. We also augmented her data with annual earnings data for nonrestated fiscal years (which we use to construct our measures of earnings history), which we collected from Compustat (data item 172), and stock returns data, which we retrieved from CRSP.

${ }^{16}$ The number of restatements continues to increase. According to Huron Consulting Group (quoted in Bryan et al. 2005), there were 323 restatements in 2003 and 414 in 2004. Jeff Szafran, Huron's managing director, attributes the 2004 increase to the "unprecedented level of regulatory and audit scrutiny, driven primarily by the Sarbanes-Oxley Act of 2002.” Apparently casting a wider net, Glass Lewis \& Co. reports 1,195 restatements by U.S. firms in 2005.

${ }^{17}$ Currentmag takes a nonzero value for 606 observations. Laggedmag takes a nonzero value for 389 observations, of which 224 involve nonzero restatements of earnings in one prior year, 106 in two prior years, 43 in three prior years, 12 in four prior years, and four in five prior years. ${ }^{18}$ This is the case in our hypothetical example above. The most recent restatement was for the first two quarters of 1998, which we treat as a fiscal year.

${ }^{19}$ In calculating undoearngrow and undoearnpos, we examined histories or earnings up to seven years prior to the most recent fiscal year restated. Of the 821 restatement observations, nine have continuous histories of earnings growth of seven years or more, five of which were eliminated by 
the restatement, while 130 observations have continuous histories of positive earnings of seven years or more, 22 of which were eliminated by the restatement. Undoearngrow and undoearnpos can take values of one because of any year that is both involved in the restatement and part of the prior history of earnings growth or positive earnings, respectively.

${ }^{20}$ Both undoearngrow and undoearnpos take values of one for 48 (6\%) of the observations.

${ }^{21}$ Given the size of our sample, we chose four years as the cutoff for grow 4 and pos 4 in an attempt to obtain a sizeable number of observations with a substantial history of earnings growth or positive earnings. The use of longer histories of earnings growth or positive earnings (e.g., the five-year history examined by Barth et al. 1999) reduces the number of observations with such histories significantly, especially for earnings growth, whereas shorter histories provide less contrast with our primary variables.

${ }^{22} \mathrm{Wu}$ (2003) classifies the primary reason for/line items affected by the restatement into nine categories: 1) both revenue and operating expenses, 2) revenue only, 3) operating expenses only, 4) loan loss allowances, 5) mergers and acquisitions, 6) in-process research and development, 7) reclassification, 8) errors, and 9) other. We include categories 1 and 2 in our indicator variable revenue.

${ }^{23}$ See note 14.

${ }^{24}$ For example, this conjecture is consistent with Burgstahler and Dichev (1997) and Dechow et al.'s (2003) findings that firms with (even slightly) positive earnings have greater cash flow and various other indicators of solvency than do firms with (even slightly) negative earnings. Moreover, we determined that 40 (4.9\%) of the firms in our sample declared bankruptcy in the year following the restatement announcement, and that firms with pos $4=0$ are $50 \%$ more likely to 
go bankrupt in the year following the restatement than are firms with pos $4=1$ (5.7\% versus 3.8\%, respectively).

${ }^{25}$ While we predict and find that the intercept is negative in the return analysis, we make no prediction about the intercept in the logit estimation of equation (3), because the estimated intercept adjusts to yield the sample average probability of a class action lawsuit, given the means of and estimated slope coefficients on the explanatory variables in equation (3). 


\section{References}

Accounting Principles Board (APB) Opinion No. 20, 1971, Accounting Changes.

Agrawal, A., and S. Chadha. 2004. Corporate governance and accounting scandals. Journal of Law and Economics, forthcoming.

Anderson, K., and T. Yohn. 2002. The effect of 10-K restatements on firm value, information asymmetries, and investors' reliance on earnings. Working paper, Georgetown University, Washington, D.C.

Antle, R., J. Demski, and S. Ryan. 1994. Multiple sources of information, valuation, and accounting earnings. Journal of Accounting, Auditing \& Finance 9: 675-696.

Ball, R., and P. Brown. 1968. An empirical evaluation of accounting income numbers. Journal of Accounting Research (Autumn): 159-178.

Ball, R., and R. Watts. 1972. Some time-series properties of accounting income. Journal of Finance (June): 663-681.

Banyi, M. 2006. An Evaluation of the causes and consequences of in-process research and development restatements. Working paper, Oregon State University, Corvalis, OR.

Brooks, L., and D. Buckmaster. 1980. First-difference signals and accounting income time-series properties. Journal of Business, Finance, and Accounting (Autumn): 437-454.

Barth, M., J. Elliott, and M. Finn. 1999. Market rewards associated with patterns of increasing earnings. Journal of Accounting Research 37: 387-413.

Beaver, W., and M. McNichols. 1998. The characteristics and valuation of loss reserves in the property and casualty insurance industry. Review of Accounting Studies 3: 73-95. 
and 2001. Do stock prices of property casualty insurers fully reflect information about earnings, cash flows, and development. Review of Accounting Studies 6: 197-200. Beneish, M. 1999. Incentives and penalties related to earnings overstatements that violate GAAP. The Accounting Review 74: 425-457.

Bonner, S., Z. Palmrose, and M. Young. 1998. Fraud type and auditor litigation: An analysis of SEC accounting and auditing enforcement releases. The Accounting Review 73: 503-532.

Bryan, S., S. Lilien, W. Ruland, and W. Sinnett, 2005. Undoing the past: Implications of earnings restatements. Financial Executive, March, 42-44.

Burgstahler, D., and I. Dichev. 1997. Earnings management to avoid earnings decreases and losses. Journal of Accounting and Economics 24: 99-126.

Burns, N., and S. Kedia. 2004. The impact of performance-based compensation on misreporting. Working paper, University of Georgia, Athens, GA.

Callen, J., S. Robb, and D. Segal. 2003. Revenue manipulation and restatements by loss firms. Working paper, University of Toronto, ON, Canada.

Dechow, P., R. Sloan, and A. Sweeney. 1996. Causes and consequences of earnings manipulation: An analysis of firms subject to enforcement actions by the SEC. Contemporary Accounting Research 13: 1-36.

Dechow, P., S. Richardson, and I. Tuna. 2003. Why are earnings kinky? An examination of the earnings management explanation. Review of Accounting Studies 8: 355-384.

Desai, H., C. Hogan, and M. Wilkins. 2006. The reputational penalty for aggressive accounting: Earnings restatements and management turnover. The Accounting Review, forthcoming.

Defond, M., and J. Jiambalvo. 1991. Incidence and circumstances of accounting errors. The Accounting Review 66: 643-655. 
Diebold, F., and G. Rudebusch. 1991. Forecasting output with the composite leasing index: A real-time analysis. Journal of the American Statistical Association 86: 603-610.

Dowdell, T., and E. Press. 2001. Restatement of in-process research and development write-offs: The impact of SEC scrutiny. Working paper, Temple University, Philadelphia, PA.

Feroz, E., K. Park, and V. Pastena. 1991. The financial and market effects of the SEC’s accounting and auditing enforcement releases. Journal of Accounting Research 29 (Supplement): 107-142.

Glass Lewis \& Co. Getting it Wrong the First Time. Restatements trend alert, March 2, 2006.

Griffin, P. 2003. A league of their own? Financial analysts’ responses to restatements and corrective disclosures. Journal of Accounting, Auditing, \& Finance 18: 479-528.

Grundfest, J., and M. Perino. 1997. Securities litigation reform: The first year’s experience. Working paper, Stanford University, Palo Alto, CA.

Howard, M. 1991. The Lessons of History. New Haven and London: Yale University Press.

Hribar, P., and N. Jenkins. 2004. The effect of accounting restatements on earnings revisions and the estimated cost of capital. Review of Accounting Studies 9: 337-356.

Kedia, S., and T. Philippon. 2006. The economics of fraudulent accounting. Working paper, Rutgers University, Newark, NJ.

Khan, M. 2005. Are accruals really mispriced? Evidence from tests of an intertemporal capital asset pricing model. Working paper, University of Toronto, ON, Canada.

Kinney, W., and L. McDaniel. 1989. Characteristics of firms correcting previously reported quarterly earnings. Journal of Accounting and Economics 11: 71-93.

Kravet, T., and T. Shevlin. 2006. Accounting restatements and information risk. Working paper, University of Washington, Seattle, WA. 
Lev, B. 2003. Corporate earnings: Facts and fiction. Journal of Economic Perspectives 17: 2750.

Lu, Y. 2003. Earnings management and securities ligitation. Working paper, Stanford University, Stanford, CA.

Lundholm, R. 1999. Reporting on the past: A new approach to improving accounting today. Accounting Horizons 13: 315-323. . 2003. Historical accounting and the endogenous credibility of current disclosures. Journal of Accounting, Auditing \& Finance 18: 207-229.

Mankiw, G., and M. Shapiro. 1986. News or noise: An analysis of GNP revisions. Survey of Current Business May: 20-25.

Myers, J., and D. Skinner. 2002. Earnings momentum and earnings management. Working paper, University of Michigan, Ann Arbor, MI.

Myers, J., L. Myers, Z. Palmrose, and S. Scholz. 2004. Mandatory auditor rotation: Evidence from restatements. Working paper, University of Illinois at Urbana-Champaign, IL. , and D. Skinner. 2002. Earnings momentum and earnings management. Working paper, University of Michigan, Ann Arbor, MI.

Palmrose, Z., V. Richardson, S. Scholz. 2004. Determinants of market reactions to restatement announcements. Journal of Accounting \& Economics 37: 59-89.

Palmrose, Z., and S. Scholz. 2004. The circumstances and legal consequences of non-GAAP reporting: Evidence from restatements. Contemporary Accounting Research 21: 139-180.

Petroni, K. 1992. Optimistic reporting in the property-casualty insurance industry. Journal of Accounting and Economics 15: 485-508. 
S. Ryan, and J. Wahlen. 2000. Discretionary and non-discretionary revisions of loss reserves by property-casualty insurers: Differential implications for future profitability, risk, and market value. Review of Accounting Studies 5: 95-125.

Richardson, S., I. Tuna, and M. Wu. 2003. Capital market pressures and earnings management: The case of earnings restatements. Working paper, University of Pennsylvania, Philadelphia, PA.

Ryan, S. 1997. A survey of research relating accounting numbers to systematic equity risk, with implications for risk disclosure policy and future research. Accounting Horizons 11: 8295.

Skinner, D., and R. Sloan. 2002. Earnings surprises, growth expectations, and stock returns. Review of Accounting Studies 7: 289-312.

Summers, S., and J. Sweeney. 1998. Fraudulently misstated financial statements and insider trading: An empirical analysis. The Accounting Review 73: 131-146.

United States General Accounting Office. 2002. Financial statement restatements: Trends, market impacts, regulatory responses, and remaining challenges. October.

Wu, M. 2003. Earnings restatements: A capital markets perspective. Working paper, Hong Kong University of Science and Technology, Hong Kong. 
Table 1

Sample Composition

Panel A: Number of Observations Lost Due to Data Requirements

Sample of $10-\mathrm{K}$ or $10-\mathrm{Q}$ restatements

Observations without perm number, cusip, or cnum, and so information on attributes

Subtotal

Observations not on CRSP or with missing CRSP data

Subtotal

Observations not on Compustat or with missing Compustat data

$\underline{65}$

Regression sample

821

Observations with missing restatement amounts (set to zero)

$\underline{6}$

Observations with nonzero restatement amounts

Panel B: Number of Observations by Five-Year Period

1977-1982 (6 years) $\quad 12$

1983-1987 84

1988-1992 100

1993-1997 172

1998-2002 $\underline{453}$

Total 821 
Table 2

Descriptive Statistics

Panel A: Indicator Variable Counts

\begin{tabular}{lcc} 
& No. of observations & Percentage of total (821) observations \\
\cline { 2 - 3 } current $=1$ & 661 & $81 \%$ \\
undoearngrow $=1$ & 96 & $12 \%$ \\
undoearnpos $=1$ & 153 & $19 \%$ \\
revenue $=1$ & 334 & $41 \%$ \\
nonumbers $=1$ & 269 & $33 \%$ \\
SEC $=1$ & 193 & $24 \%$ \\
fraud $=1$ & 92 & $11 \%$
\end{tabular}

Panel B: Details on Timeliness of Restatement Announcements

\begin{tabular}{|c|c|c|c|}
\hline & current $=1$ & $\leq 1$ year lagged & $\geq 1$ year lagged \\
\hline No. observations & 661 & 143 & 17 \\
\hline Percentage of total observations & $81 \%$ & $17 \%$ & $2 \%$ \\
\hline
\end{tabular}

Panel C: Details on Earnings History Indicator Variables

No. observations

(percentage of total observations)

Earnings growth $\quad \underline{\text { Positive earnings }}$

No history

459

(56\%)

362

(44\%)

96

(12\%)

undoearngrow $=1$
336

(41\%)

485

(59\%)

153

(19\%)

undoearnpos $=1$ 
Table 2 (continued)

Panel D: Means and Quartiles of Continuous Variables

$\begin{array}{lcccccc} & \underline{\text { mean }} & \underline{\text { minimum }} & \underline{\mathbf{2 5 \%}} & \underline{\text { median }} & \underline{\mathbf{7 5 \%}} & \underline{\text { maximum }} \\ \text { mag } & -0.065 & -1.198 & -0.058 & -0.014 & 0 & 0.219 \\ \text { currentmag } & -0.034 & -0.798 & -0.024 & -0.003 & 0 & 0.168 \\ \text { laggedmag } & -0.030 & -1.198 & -0.015 & 0 & 0 & 0.168 \\ R_{-1,1} & -0.107 & -0.670 & -0.192 & -0.061 & 0.002 & 0.286\end{array}$

Panel E: Pearson Correlations of Variables in Primary Returns Analysis

\begin{tabular}{|c|c|c|c|c|c|c|c|c|c|c|}
\hline & (1) & (2) & (3) & (4) & (5) & (6) & (7) & (8) & (9) & $(\mathbf{1 0})$ \\
\hline current (1) & 1 & & & & & & & & & \\
\hline $\operatorname{mag}(2)$ & 0.05 & 1 & & & & & & & & \\
\hline currentmag (3) & -0.15 & 0.73 & 1 & & & & & & & \\
\hline laggedmag (4) & 0.23 & 0.70 & 0.03 & 1 & & & & & & \\
\hline undoearngrow (5) & -0.08 & -0.12 & -0.12 & -0.05 & 1 & & & & & \\
\hline undoearnpos (6) & 0.05 & -0.26 & -0.22 & -0.15 & 0.29 & 1 & & & & \\
\hline revenue (7) & 0.08 & -0.08 & -0.04 & -0.08 & 0.05 & 0.07 & 1 & & & \\
\hline nonumbers (8) & 0.03 & -0.11 & -0.03 & -0.12 & 0.18 & 0.14 & 0.15 & 1 & & \\
\hline$S E C(9)$ & -0.08 & 0.04 & 0.01 & 0.04 & 0.01 & -0.04 & -0.11 & 0.03 & 1 & \\
\hline fraud (10) & -0.02 & -0.04 & -0.00 & -0.06 & 0.10 & 0.10 & 0.16 & 0.26 & -0.11 & 1 \\
\hline$R_{-1,1}$ & $-\mathbf{0 . 0 7}$ & 0.12 & 0.13 & 0.04 & -0.18 & -0.19 & -0.22 & $-\mathbf{0 . 3 0}$ & 0.15 & -0.27 \\
\hline
\end{tabular}




\section{Table 2 (continued)}

Notes: All indicator variables take a value of one if the condition is present and take the value of zero otherwise. The continuous variables are winsorized at the outside $1 \%$ tails of their

distributions. Correlations significant at the $5 \%$ level or better in a two-tailed test are in boldface.

The variables are defined as:

current

mag

currentmag

laggedmag

undoearngrow

undoearnpos

revenue

nonumbers

SEC

fraud

$R_{-1,1}$ an indicator variable for restatements announced no later than four months after the end of the fiscal year of the most recent fiscal year restated the amount of restatements divided by market capitalization at the beginning of the restatement announcement window the amount of current restatements for most recent fiscal year divided by market capitalization at the beginning of the restatement announcement window

the amount of current restatements for fiscal years other than the most recent, and of lagged restatements divided by market capitalization at the beginning of the restatement announcement window an indicator variable for restatements that eliminate or reduce the number of consecutive fiscal years the firm has reported earnings growth; the last fiscal year includes only the period up to the most recent fiscal quarter restated

an indictor variable for restatements that eliminate or reduce the number of consecutive fiscal years the firm has reported positive earnings; the last fiscal year includes only the portion up to the most recent fiscal quarter restated

an indicator variable for restatements involving revenue recognition an indicator variable for restatements for which the amount of the restatement is not disclosed at the restatement announcement date an indicator variable for SEC-enforced restatements an indicator variable for restatements involving admissions of fraud beta-adjusted returns for the three-day period surrounding the restatement announcement date 
Table 3

\section{Primary Returns Analysis}

$$
\begin{aligned}
R_{-1,+1}=\alpha & +\alpha_{c} \text { current }+\beta \text { mag }+\beta_{c} \text { currentmag }+\beta_{l} \text { laggedmag }+\gamma_{g} \text { undoearngrow } \\
& +\gamma_{p} \text { undoearnpos }+\delta_{r} \text { revenue }+\delta_{n} \text { nonumbers }+\delta_{s} S E C+\delta_{f} \text { fraud } .
\end{aligned}
$$

\section{Prior research Distinguish current and Add effect of restatement}

lagged restatements

\begin{tabular}{|c|c|c|c|}
\hline intercept (-) & $\begin{array}{c}-0.053 \\
(-5.9)\end{array}$ & $\begin{array}{c}-0.044 \\
(-3.0)\end{array}$ & $\begin{array}{c}-0.035 \\
(-2.3)\end{array}$ \\
\hline current (?) & -- & $\begin{array}{c}-0.010 \\
(-0.7)\end{array}$ & $\begin{array}{c}-0.013 \\
(-0.9)\end{array}$ \\
\hline $\operatorname{mag}(+)$ & $\begin{array}{c}0.077 \\
(2.1)\end{array}$ & -- & -- \\
\hline currentmag $(+)$ & -- & $\begin{array}{c}0.175 \\
(3.4)\end{array}$ & $\begin{array}{l}0.128 \\
(2.5)\end{array}$ \\
\hline laggedmag $(+)$ & -- & $\begin{array}{c}-0.031 \\
(-0.6)\end{array}$ & $\begin{array}{r}-0.050 \\
(-0.9)\end{array}$ \\
\hline undoearngrow (-) & -- & -- & $\begin{array}{c}-0.052 \\
(-2.8)\end{array}$ \\
\hline undoearnpos (-) & -- & -- & $\begin{array}{r}-0.039 \\
(-2.5)\end{array}$ \\
\hline revenue $(-)$ & $\begin{array}{c}-0.052 \\
(-4.4)\end{array}$ & $\begin{array}{c}-0.052 \\
(-4.4)\end{array}$ & $\begin{array}{c}-0.050 \\
(-4.3)\end{array}$ \\
\hline nonumbers (-) & $\begin{array}{c}-0.087 \\
(-6.9)\end{array}$ & $\begin{array}{c}-0.088 \\
(-7.0)\end{array}$ & $\begin{array}{r}-0.079 \\
(-6.3)\end{array}$ \\
\hline $\operatorname{SEC}(+)$ & $\begin{array}{c}0.050 \\
(3.7)\end{array}$ & $\begin{array}{c}0.049 \\
(3.7)\end{array}$ & $\begin{array}{c}0.049 \\
(3.7)\end{array}$ \\
\hline fraud (-) & $\begin{array}{c}-0.098 \\
(-4.4)\end{array}$ & $\begin{array}{c}-0.100 \\
(-5.3)\end{array}$ & $\begin{array}{c}-0.094 \\
(-5.1)\end{array}$ \\
\hline$R^{2}$ & $17.4 \%$ & $18.4 \%$ & $20.2 \%$ \\
\hline
\end{tabular}

\section{on earnings history}

Notes: All regressions include 821 observations. The sample is described in Table 1 . The variables are defined and winsorization rules described in the notes to Table 2. Predictions for the sign of coefficients are indicated in parentheses next to the variable name. Student $t$ statistics appear parenthetically beneath the estimated coefficients. Coefficients appear in boldface if significant at the $5 \%$ level or better in a one-tailed test if directional predictions are made and a two-tailed test otherwise. 
Table 4

Returns Analysis for Restatement Timeliness and Fraud Subsamples

$$
\begin{aligned}
R_{-1,+1}=\alpha & +\alpha_{c} \text { current }+\beta_{c} \text { currentmag }+\beta_{l} \text { laggedmag }+\gamma_{g} \text { undoearngrow } \\
& +\gamma_{p} \text { undoearnos }+\delta_{r} \text { revenue }+\delta_{n} \text { nonumbers }+\delta_{s} S E C+\delta_{f} \text { fraud } .
\end{aligned}
$$

\begin{tabular}{|c|c|c|c|c|c|c|}
\hline & $\underline{\text { Current }}$ & Lagged & Difference & Fraud & $\underline{\text { No Fraud }}$ & $\underline{\text { Difference }}$ \\
\hline intercept (-) & $\begin{array}{c}-0.053 \\
(-5.9)\end{array}$ & $\begin{array}{c}-0.017 \\
(-1.0)\end{array}$ & $\begin{array}{c}-0.036 \\
(-1.5)\end{array}$ & $\begin{array}{c}-0.160 \\
(-2.3)\end{array}$ & $\begin{array}{c}-0.029 \\
(-1.9)\end{array}$ & $\begin{array}{c}-0.131 \\
(-2.5)\end{array}$ \\
\hline current (?) & -- & -- & -- & $\begin{array}{l}0.024 \\
(0.4)\end{array}$ & $\begin{array}{c}-0.019 \\
(-1.2)\end{array}$ & $\begin{array}{c}0.043 \\
(0.9)\end{array}$ \\
\hline currentmag $(+)$ & $\begin{array}{c}0.121 \\
(2.2)\end{array}$ & -- & -- & $\begin{array}{c}-0.052 \\
(-0.2)\end{array}$ & $\begin{array}{c}0.140 \\
(2.7)\end{array}$ & $\begin{array}{l}-.192 \\
(-1.0)\end{array}$ \\
\hline laggedmag $(+)$ & $\begin{array}{c}0.076 \\
(.7)\end{array}$ & $\begin{array}{c}-0.098 \\
(-1.8)\end{array}$ & $\begin{array}{c}0.174 \\
(1.4)\end{array}$ & $\begin{array}{c}0.033 \\
(0.2)\end{array}$ & $\begin{array}{c}-0.071 \\
(-1.2)\end{array}$ & $\begin{array}{c}0.104 \\
(0.7)\end{array}$ \\
\hline undoearngrow (-) & $\begin{array}{c}-0.056 \\
(-2.5)\end{array}$ & $\begin{array}{l}-0.037 \\
(-1.2)\end{array}$ & $\begin{array}{c}-0.019 \\
(-0.4)\end{array}$ & $\begin{array}{c}-0.026 \\
(-0.4)\end{array}$ & $\begin{array}{c}-0.050 \\
(-2.5)\end{array}$ & $\begin{array}{c}0.024 \\
(0.4)\end{array}$ \\
\hline undoearnpos (-) & $\begin{array}{c}-0.038 \\
(-2.2)\end{array}$ & $\begin{array}{l}-0.052 \\
(-1.5)\end{array}$ & $\begin{array}{c}0.014 \\
(0.3)\end{array}$ & $\begin{array}{c}-0.070 \\
(-1.3)\end{array}$ & $\begin{array}{l}-0.037 \\
(-2.3)\end{array}$ & $\begin{array}{c}-0.033 \\
(-0.7)\end{array}$ \\
\hline revenue $(-)$ & $\begin{array}{c}-0.055 \\
(-4.1)\end{array}$ & $\begin{array}{c}-0.008 \\
(-.3)\end{array}$ & $\begin{array}{l}-0.037 \\
(-1.5)\end{array}$ & $\begin{array}{c}-0.026 \\
(-0.6)\end{array}$ & $\begin{array}{c}-0.054 \\
(-4.5)\end{array}$ & $\begin{array}{c}0.028 \\
(0.8)\end{array}$ \\
\hline nonumbers (-) & $\begin{array}{c}-0.070 \\
(-4.8)\end{array}$ & $\begin{array}{c}-0.121 \\
(-4.9)\end{array}$ & $\begin{array}{c}0.051 \\
(1.5)\end{array}$ & $\begin{array}{c}-0.107 \\
(-2.3)\end{array}$ & $\begin{array}{c}-0.076 \\
(-5.8)\end{array}$ & $\begin{array}{c}-0.031 \\
(-0.8)\end{array}$ \\
\hline $\operatorname{SEC}(+)$ & $\begin{array}{c}0.063 \\
(4.0)\end{array}$ & $\begin{array}{c}-0.004 \\
(-.2)\end{array}$ & $\begin{array}{c}0.067 \\
(2.1)\end{array}$ & $\begin{array}{l}0.107 \\
(1.6)\end{array}$ & $\begin{array}{c}0.045 \\
(3.3)\end{array}$ & $\begin{array}{c}0.062 \\
(1.1)\end{array}$ \\
\hline fraud (-) & $\begin{array}{c}-0.082 \\
(-3.8)\end{array}$ & $\begin{array}{c}-0.153 \\
(-4.6)\end{array}$ & $\begin{array}{c}0.071 \\
(1.6)\end{array}$ & -- & -- & -- \\
\hline$R^{2}$ & $18.4 \%$ & $35.9 \%$ & & $16.2 \%$ & $14.0 \%$ & \\
\hline \# observations & 661 & 160 & & 92 & 729 & \\
\hline
\end{tabular}

Notes: The sample is described in Table 1. The variables are defined and winsorization rules described in the notes to Table 2. Predictions for the sign of coefficients are indicated in parentheses next to the variable name. Student $t$ statistics appear parenthetically beneath the estimated coefficients. Coefficients appear in boldface if significant at the $5 \%$ level or better in a one-tailed test if directional predictions are made and a two-tailed test otherwise. 


\section{Table 5}

Supplemental Returns Analysis Refining Results for Earnings History

$$
\begin{aligned}
R_{-1,+1}=\alpha & +\alpha_{c} \text { current }+\beta_{c} \text { currentmag }+\beta_{l} \text { laggedmag }+\gamma_{g} \text { undoearngrow } \\
& +\gamma_{g 4}(\text { undoearngrow } \times \text { grow } 4)+\gamma_{p} \text { undoearnpos }+\gamma_{p 4}(\text { undoearnpos } \times \text { pos } 4)+ \\
& +\gamma_{g p} \text { undoearngrowpos }+\delta_{r} \text { revenue }+\delta_{n} \text { nonumbers }+\delta_{s} S E C+\delta_{f} \text { fraud } .
\end{aligned}
$$

Distinguish earnings histories Combine histories of earnings longer than four years

intercept (-)
current $(?)$
currentmag $(+)$
laggedmag $(+)$
undoearngrow $(-)$
undoearngrow ${ }^{*}$ grow4
$(-)$
undoearnpos $(-)$
undoearnpos*pos4 $(-)$
undoearngrowpos $(-)$
revenue $(-)$
Sraud $(-)$
nonumbers $(-)$

$-\mathbf{0 . 0 3 2}$

$(-2.1)$

$-0.015$

$(-1.0)$

0.126

(2.4)

$-0.062$

$(-1.1)$

$-\mathbf{0 . 0 4 0}$

$(-2.0)$

$-0.065$

$(-2.1)$

$-\mathbf{0 . 0 7 2}$

(-3.8)

0.074

(2.8)

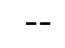

growth or positive earnings

$-\mathbf{0 . 0 3 5}$

(-2.4)

$-0.010$

$(-0.7)$

0.126

(2.4)

$-0.052$

$(-1.0)$
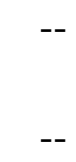

$-\mathbf{0 . 0 5 7}$

(-4.2)

$-0.051$

$(-4.4)$

$-0.050$

(-4.3)

$-0.081$

(-6.4)

$-0.082$

(-6.5)

0.047

(3.5)

0.049

(3.7)

$-0.095$

$-0.097$

(-5.1)

(-5.2)

20.1\% 


\section{Table 5 (continued)}

Notes: All regressions include 821 observations. The sample is described in Table 1 . The variables are defined and winsorization rules described in the notes to Table 2, except that grow4 is an indicator variable for a history of earnings growth prior to the earnings restatement of four fiscal years or longer, pos 4 is an indicator variable for a history of positive earnings prior to the earnings restatement of four fiscal years or longer, and undoearngrowpos is an indicator variable that equals one if either undoearngrow or undoearnpos equals one. Predictions for the sign of coefficients are indicated in parentheses next to the variable name. Student $t$ statistics appear parenthetically beneath the estimated coefficients. Coefficients appear in boldface if significant at the $5 \%$ level or better in a one-tailed test if directional predictions are made and a two-tailed test otherwise. 
Table 6

Descriptive Statistics for No-Lawsuit and Lawsuit Subsamples

Panel A: Indicator Variable Counts for No-Lawsuit and Lawsuit Subsamples

\begin{tabular}{|c|c|c|c|}
\hline & $\frac{\text { No. observations }}{\frac{\text { (percentage of }}{\text { column total) }}}$ & $\frac{\text { No. observations }}{\frac{\text { (percentage of }}{\text { column total) }}}$ & $\frac{\begin{array}{c}\chi^{2} \text { test of } \\
\text { independence }\end{array}}{\text { across subsamples }}$ \\
\hline $\begin{array}{l}\text { all observations in } \\
\text { column }\end{array}$ & $\begin{array}{c}610 \\
(100 \%) \\
\text { [74\% of overall } \\
\text { sample] }\end{array}$ & $\begin{array}{c}211 \\
(100 \%) \\
\text { [26\% of overall } \\
\text { sample] }\end{array}$ & - \\
\hline current $=1$ & $\begin{array}{c}477 \\
(78 \%)\end{array}$ & $\begin{array}{c}184 \\
(87 \%)\end{array}$ & $\begin{array}{c}8.1 \\
(0.00)\end{array}$ \\
\hline undoearngrow $=1$ & $\begin{array}{c}50 \\
(8 \%)\end{array}$ & $\begin{array}{c}46 \\
(22 \%)\end{array}$ & $\begin{array}{c}28.1 \\
(0.00)\end{array}$ \\
\hline undoearnpos $=1$ & $\begin{array}{c}93 \\
(15 \%)\end{array}$ & $\begin{array}{c}60 \\
(28 \%)\end{array}$ & $\begin{array}{c}18.0 \\
(0.00)\end{array}$ \\
\hline revenue $=1$ & $\begin{array}{c}208 \\
(34 \%)\end{array}$ & $\begin{array}{c}126 \\
(60 \%)\end{array}$ & $\begin{array}{c}42.6 \\
(0.00)\end{array}$ \\
\hline nonumbers $=1$ & $\begin{array}{c}141 \\
(23 \%)\end{array}$ & $\begin{array}{c}128 \\
(61 \%)\end{array}$ & $\begin{array}{l}100.3 \\
(0.00)\end{array}$ \\
\hline$S E C=1$ & $\begin{array}{c}154 \\
(25 \%)\end{array}$ & $\begin{array}{c}39 \\
(18 \%)\end{array}$ & $\begin{array}{c}4.0 \\
(0.05)\end{array}$ \\
\hline fraud $=1$ & $\begin{array}{c}34 \\
(6 \%)\end{array}$ & $\begin{array}{c}58 \\
(27 \%)\end{array}$ & $\begin{array}{c}75.7 \\
(0.00)\end{array}$ \\
\hline
\end{tabular}

Panel B: Means and Medians of Continuous Variables

\begin{tabular}{|c|c|c|c|c|c|c|}
\hline & \multicolumn{3}{|c|}{ means } & \multicolumn{3}{|c|}{ medians } \\
\hline & $\frac{\text { lawsuit }=}{\underline{0}}$ & $\frac{\text { lawsuit }=}{\underline{1}}$ & $\frac{t \text { test of }}{\text { difference }}$ & $\frac{\text { lawsuit }=}{\underline{0}}$ & $\frac{\text { lawsuit }=}{\underline{1}}$ & $\underset{\text { difference }}{\chi^{2} \text { test of }}$ \\
\hline currentmag & -0.029 & -0.050 & $\begin{array}{c}2.4 \\
(0.01)\end{array}$ & -0.001 & -0.011 & $\begin{array}{c}22.0 \\
(0.00)\end{array}$ \\
\hline laggedmag & -0.028 & -0.036 & $\begin{array}{c}.9 \\
(0.67)\end{array}$ & 0 & 0 & $\begin{array}{c}6.3 \\
(0.01)\end{array}$ \\
\hline$R_{-1,1}$ & -0.057 & -0.250 & $\begin{array}{c}15.5 \\
(0.00)\end{array}$ & -0.037 & -0.226 & $\begin{array}{c}96.1 \\
(0.00)\end{array}$ \\
\hline$R_{-127,-2}$ & -0.075 & -0.264 & $\begin{array}{c}3.3 \\
(0.01)\end{array}$ & -0.167 & -0.379 & $\begin{array}{c}23.5 \\
(0.00)\end{array}$ \\
\hline
\end{tabular}




\section{Table 6 (continued)}

Panel C: Pearson Correlations of Lawsuit with Explanatory Variables

\begin{tabular}{lc} 
& $\underline{\text { lawsuit }}$ \\
\cline { 2 - 2 } current & $\mathbf{0 . 1 0}$ \\
currentmag & $\mathbf{- 0 . 0 8}$ \\
laggedmag & -0.03 \\
undoearngrow & $\mathbf{0 . 1 9}$ \\
undoearnpos & $\mathbf{0 . 1 5}$ \\
revenue & $\mathbf{0 . 2 3}$ \\
nonumbers & $\mathbf{0 . 3 5}$ \\
SEC & $-\mathbf{0 . 0 7}$ \\
fraud & $\mathbf{0 . 3 0}$ \\
$R_{-1,1}$ & $\mathbf{- 0 . 4 8}$ \\
$R_{-127,-2}$ & $\mathbf{- 0 . 1 2}$ \\
\hline
\end{tabular}

Notes: The sample is described in Table 1. The variables are defined and winsorization rules described in the notes to Table 2, except that lawsuit is an indicator variable for a class action lawsuit filed as a consequence of the restatement, and $R_{-127,-2}$ is the buy-and-hold beta-adjusted return for the six months preceding the restatement announcement period window. Boldface highlights tests of differences across the no-lawsuit and lawsuit samples and correlations significant at the $5 \%$ level or better in a two-tailed test. In Panel C, the $\xi^{2}$ test for differences of the medians of laggedmag across the two samples is nonzero and significant despite the identical medians for this variable because of the different proportion of observations with value equal to the median across the samples. 
Table 7

\section{Predicting Class Action Lawsuits \\ OLS and Logit Estimation \\ Overall Sample}

$$
\begin{aligned}
\text { lawsuit }= & \alpha+\alpha_{c} \text { current }+\beta_{c} \text { currentmag }+\beta_{l} \text { laggedmag }+\gamma_{g} \text { undoearngrow } \\
& +\gamma_{p} \text { undoearnpos }+\delta_{r} \text { revenue }+\delta_{n} \text { nonumbers }+\delta_{s} S E C+\delta_{f} \text { fraud } \\
& +\phi_{a n n} R_{-1,+1}+\phi_{\text {pre }} R_{-127,-2} .
\end{aligned}
$$

\begin{tabular}{|c|c|c|c|c|c|c|}
\hline & $\underline{\text { OLS }}$ & $\underline{\text { Logit }}$ & $\frac{\text { Effect on }}{\text { probability }}$ & $\underline{\text { OLS }}$ & $\underline{\text { Logit }}$ & $\frac{\text { Effect on }}{\text { probability }}$ \\
\hline Intercept (?) & $\begin{array}{c}0.094 \\
(.3)\end{array}$ & $\begin{array}{c}-2.849 \\
(-9.6)\end{array}$ & -- & $\begin{array}{c}-0.027 \\
(-0.8)\end{array}$ & $\begin{array}{l}-3.430 \\
(-10.2)\end{array}$ & -- \\
\hline current (?) & $\begin{array}{c}0.086 \\
(2.4)\end{array}$ & $\begin{array}{c}0.696 \\
(2.5)\end{array}$ & $11.8 \%$ & $\begin{array}{c}0.078 \\
(2.3)\end{array}$ & $\begin{array}{c}0.700 \\
(2.4)\end{array}$ & $10.9 \%$ \\
\hline currentmag (?) & $\begin{array}{c}-0.142 \\
(-1.1)\end{array}$ & $\begin{array}{c}-0.771 \\
(-0.9)\end{array}$ & $-13.0 \%$ & $\begin{array}{c}0.029 \\
(.2)\end{array}$ & $\begin{array}{l}0.403 \\
(0.5)\end{array}$ & $6.3 \%$ \\
\hline laggedmag (?) & $\begin{array}{c}0.082 \\
(0.6)\end{array}$ & $\begin{array}{c}\mathbf{0 . 4 6 9} \\
(.5)\end{array}$ & $7.9 \%$ & $\begin{array}{l}0.110 \\
(1.0)\end{array}$ & $\begin{array}{l}.532 \\
(0.5)\end{array}$ & $8.3 \%$ \\
\hline undoearngrow $(+)$ & $\begin{array}{c}0.141 \\
(3.1)\end{array}$ & $\begin{array}{c}0.774 \\
(2.8)\end{array}$ & $13.1 \%$ & $\begin{array}{c}0.100 \\
(2.4)\end{array}$ & $\begin{array}{l}0.606 \\
(2.0)\end{array}$ & $9.4 \%$ \\
\hline undoearnpos $(+)$ & $\begin{array}{l}0.047 \\
(1.3)\end{array}$ & $\begin{array}{l}0.292 \\
(1.3)\end{array}$ & $4.9 \%$ & $\begin{array}{c}0.016 \\
(0.5)\end{array}$ & $\begin{array}{l}0.163 \\
(0.6)\end{array}$ & $2.5 \%$ \\
\hline revenue $(+)$ & $\begin{array}{c}0.126 \\
(4.4)\end{array}$ & $\begin{array}{l}.775 \\
(4.2)\end{array}$ & $13.1 \%$ & $\begin{array}{r}0.082 \\
(3.0)\end{array}$ & $\begin{array}{l}0.554 \\
(2.8)\end{array}$ & $6.8 \%$ \\
\hline nonumbers $(+)$ & $\begin{array}{c}0.234 \\
(7.6)\end{array}$ & $\begin{array}{c}1.312 \\
(7.0)\end{array}$ & $22.1 \%$ & $\begin{array}{c}0.163 \\
(5.5)\end{array}$ & $\begin{array}{l}1.021 \\
(5.0)\end{array}$ & $15.9 \%$ \\
\hline $\operatorname{SEC}(-)$ & $\begin{array}{c}-0.035 \\
(-1.1)\end{array}$ & $\begin{array}{c}-0.247 \\
(-1.1)\end{array}$ & $-4.2 \%$ & $\begin{array}{c}0.016 \\
(.5)\end{array}$ & $\begin{array}{l}0.227 \\
(0.9)\end{array}$ & $3.5 \%$ \\
\hline fraud $(+)$ & $\begin{array}{c}0.276 \\
(6.1)\end{array}$ & $\begin{array}{c}1.349 \\
(5.1)\end{array}$ & $22.8 \%$ & $\begin{array}{c}0.193 \\
(4.5)\end{array}$ & $\begin{array}{l}1.041 \\
(3.7)\end{array}$ & $16.2 \%$ \\
\hline$R_{-1,1}(-)$ & -- & -- & -- & $\begin{array}{l}-0.854 \\
(-10.6)\end{array}$ & $\begin{array}{c}-5.385 \\
(-8.6)\end{array}$ & $-83.8 \%$ \\
\hline$R_{-127,-2}(-)$ & -- & -- & -- & $\begin{array}{c}-0.054 \\
(-3.0)\end{array}$ & $\begin{array}{c}-0.467 \\
(-2.6)\end{array}$ & $-7.3 \%$ \\
\hline$R^{2}$ & $21.9 \%$ & -- & -- & $32.0 \%$ & -- & -- \\
\hline model $\chi^{2}$ & -- & $100.9(d f=9)$ & -- & -- & $190.3(d f=11)$ & -- \\
\hline \% correctly classified & -- & $78.3 \%$ & -- & -- & $81.8 \%$ & -- \\
\hline \% no-lawsuit in sample & -- & $74.3 \%$ & -- & -- & $74.3 \%$ & -- \\
\hline
\end{tabular}




\section{Table 7 (continued)}

Notes: All regressions include 821 observations. The sample is described in Table 1. The variables are defined and winsorization rules described in the notes to Tables 2 and 5 . Predictions for the sign of coefficients are indicated in parentheses next to the variable name. Student $t$ statistics appear parenthetically beneath the estimated coefficients. Coefficients and model $\chi^{2}$ values in the logit estimation appear in boldface if significant at the $5 \%$ level or better in a onetailed test if directional predictions are made and a two-tailed test otherwise. The logit estimation models the probability of a lawsuit. The "effect on probability" column to the right of the column reporting a given logit estimation indicates the marginal effect on the probability of a lawsuit implied by the coefficients from that estimation when the corresponding variable increases by 1 . 


\section{Table 8 \\ Predicting Class Action Lawsuits \\ Correct Prediction Percentages for Lawsuits and No-Lawsuit Observations \\ Overall and Post-PSLRA Samples}

\begin{tabular}{|c|c|c|}
\hline & $\frac{\text { overall sample with }}{\underline{\text { return variables }}}$ & $\frac{\text { post-PSLRA sample with }}{\underline{\text { return variables }}}$ \\
\hline $\begin{array}{l}\text { observations correctly classified } \\
\text { (from Tables } 6 \text { and } 8 \text { ) }\end{array}$ & $81.8 \%$ & $82.8 \%$ \\
\hline $\begin{array}{l}\text { actual lawsuit is predicted to be } \\
\text { lawsuit }\end{array}$ & $49.3 \%$ & $61.2 \%$ \\
\hline $\begin{array}{l}\text { actual no-lawsuit is predicted to be } \\
\text { no-lawsuit }\end{array}$ & $93.0 \%$ & $92.7 \%$ \\
\hline
\end{tabular}

Note: These percentages are derived from the results of estimating equation (3) with the returns variables for the overall sample and the post-PSLRA sample reported in Tables 6 and 8. 
Table 9

\section{Predicting Class Action Lawsuits \\ OLS and Logit Estimation \\ Post-PSLRA Sample}

\begin{tabular}{|c|c|c|c|c|c|c|}
\hline \multicolumn{7}{|c|}{$\begin{array}{l}+\gamma_{p} \text { undoearnpos }+\delta_{r} \text { revenue }+\delta_{n} \text { nonumbers }+\delta_{s} S E C+\delta_{f} \text { fraud } \\
+\phi_{\text {ann }} R_{-1,+1}+\phi_{\text {pre }} R_{-127,-2}\end{array}$} \\
\hline & $\underline{\text { OLS }}$ & $\underline{\text { Logit }}$ & $\underline{\text { Effect }}$ & $\underline{\mathbf{O L S}}$ & $\underline{\text { Logit }}$ & $\frac{\text { Effect }}{\text { on prob. }}$ \\
\hline Intercept (?) & $\begin{array}{c}0.040 \\
(.8)\end{array}$ & $\begin{array}{c}-2.620 \\
(-6.9)\end{array}$ & -- & $\begin{array}{c}0.014 \\
(0.3)\end{array}$ & $\begin{array}{c}-3.078 \\
(-7.4)\end{array}$ & -- \\
\hline current (?) & $\begin{array}{c}0.058 \\
(1.2)\end{array}$ & $\begin{array}{c}0.454 \\
(1.3)\end{array}$ & $9.1 \%$ & $\begin{array}{l}.036 \\
(.8)\end{array}$ & $\begin{array}{c}0.258 \\
(0.7)\end{array}$ & $5.0 \%$ \\
\hline currentmag (?) & $\begin{array}{c}-0.159 \\
(-0.8)\end{array}$ & $\begin{array}{c}-0.926 \\
(-0.9)\end{array}$ & $-18.6 \%$ & $\begin{array}{c}-0.011 \\
(-0.1)\end{array}$ & $\begin{array}{c}0.320 \\
(0.3)\end{array}$ & $6.2 \%$ \\
\hline laggedmag (?) & $\begin{array}{c}0.170 \\
(1.0)\end{array}$ & $\begin{array}{c}0.331 \\
(0.3)\end{array}$ & $6.6 \%$ & $\begin{array}{c}0.170 \\
(1.1)\end{array}$ & $\begin{array}{c}0.118 \\
(0.1)\end{array}$ & $2.3 \%$ \\
\hline undoearngrow $(+)$ & $\begin{array}{c}0.233 \\
(3.8)\end{array}$ & $\begin{array}{c}1.370 \\
(3.7)\end{array}$ & $27.5 \%$ & $\begin{array}{c}\mathbf{0 . 1 7 7} \\
\mathbf{( 3 . 1 )}\end{array}$ & $\begin{array}{l}1.226 \\
(2.9)\end{array}$ & $23.6 \%$ \\
\hline undoearnpos $(+)$ & $\begin{array}{c}0.089 \\
(1.8)\end{array}$ & $\begin{array}{c}0.593 \\
(1.9)\end{array}$ & $11.9 \%$ & $\begin{array}{l}0.051 \\
(1.1)\end{array}$ & $\begin{array}{c}0.444 \\
(1.3)\end{array}$ & $8.6 \%$ \\
\hline revenue $(+)$ & $\begin{array}{c}0.206 \\
(5.6)\end{array}$ & $\begin{array}{c}1.069 \\
(4.7)\end{array}$ & $21.5 \%$ & $\begin{array}{c}0.132 \\
(3.9)\end{array}$ & $\begin{array}{c}0.845 \\
(3.4)\end{array}$ & $16.3 \%$ \\
\hline nonumbers $(+)$ & $\begin{array}{c}0.228 \\
(5.9)\end{array}$ & $\begin{array}{c}1.326 \\
(5.8)\end{array}$ & $26.6 \%$ & $\begin{array}{c}0.171 \\
(4.8)\end{array}$ & $\begin{array}{l}1.104 \\
(4.4)\end{array}$ & $21.3 \%$ \\
\hline$S E C(-)$ & $\begin{array}{c}-0.052 \\
(-1.3)\end{array}$ & $\begin{array}{c}-0.339 \\
(-1.2)\end{array}$ & $-6.8 \%$ & $\begin{array}{c}0.011 \\
(0.3)\end{array}$ & $\begin{array}{c}0.179 \\
(0.6)\end{array}$ & $3.4 \%$ \\
\hline $\operatorname{fraud}(+)$ & $\begin{array}{c}0.323 \\
(5.8)\end{array}$ & $\begin{array}{c}1.779 \\
(5.1)\end{array}$ & $35.7 \%$ & $\begin{array}{c}0.233 \\
(4.5)\end{array}$ & $\begin{array}{c}1.420 \\
(3.8)\end{array}$ & $27.4 \%$ \\
\hline$R_{-1,1}(-)$ & -- & -- & -- & $\begin{array}{c}-0.864 \\
(-9.0)\end{array}$ & $\begin{array}{c}-5.809 \\
(-7.2)\end{array}$ & $-112.1 \%$ \\
\hline$R_{-127,-2}(-)$ & -- & -- & -- & $\begin{array}{c}-0.054 \\
(-2.8)\end{array}$ & $\begin{array}{c}-0.484 \\
(-3.1)\end{array}$ & $-9.4 \%$ \\
\hline $\mathrm{R}^{2}$ & $29.1 \%$ & -- & -- & $39.1 \%$ & -- & -- \\
\hline model chi-square & -- & $120.9(d f=9)$ & -- & -- & $184.0(d f=11)$ & -- \\
\hline \% correctly classified & -- & $78.3 \%$ & -- & -- & $82.8 \%$ & -- \\
\hline \% no lawsuit in sample & -- & $68.5 \%$ & -- & -- & $68.5 \%$ & -- \\
\hline
\end{tabular}




\section{Table 9 (continued)}

Notes: All regressions include the 540 observations for which the restatement announcement followed the passage of the Private Securities Litigation Reform Act on December 22, 1995. The overall sample is described in Table 1. The variables are defined and winsorization rules described in the notes to Tables 2 and 5. Predictions for the sign of coefficients are indicated in parentheses next to the variable name. Student $t$ statistics appear parenthetically beneath the estimated coefficients. Coefficients and model $\chi^{2}$ values in the logit estimation appear in boldface if significant at the $5 \%$ level or better in a one-tailed test if directional predictions are made and a two-tailed test otherwise. The logit estimation models the probability of a lawsuit. The "effect on probability" column to the right of the column reporting a given logit estimation indicates the marginal effect on the probability of a lawsuit implied by the coefficients from that estimation when the corresponding variable increases by 1 . 